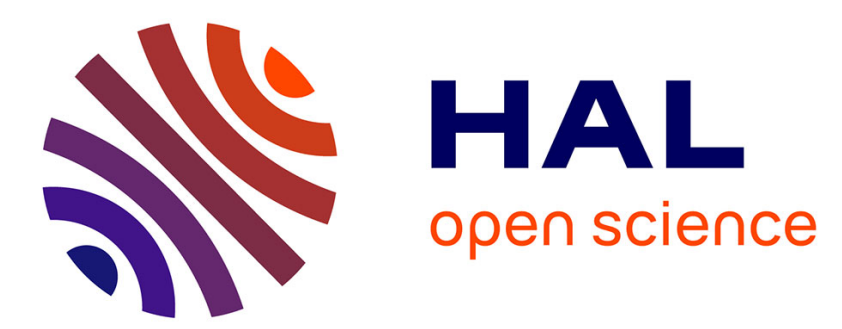

\title{
Current Account and Real Exchange Rate Changes: The Impact of Trade Openness
}

Davide Romelli, Cristina Terra, Enrico Vasconcelos

\section{To cite this version:}

Davide Romelli, Cristina Terra, Enrico Vasconcelos. Current Account and Real Exchange Rate Changes: The Impact of Trade Openness. 2015. hal-01247628

\section{HAL Id: hal-01247628 \\ https://essec.hal.science/hal-01247628}

Preprint submitted on 22 Dec 2015

HAL is a multi-disciplinary open access archive for the deposit and dissemination of scientific research documents, whether they are published or not. The documents may come from teaching and research institutions in France or abroad, or from public or private research centers.
L'archive ouverte pluridisciplinaire HAL, est destinée au dépôt et à la diffusion de documents scientifiques de niveau recherche, publiés ou non, émanant des établissements d'enseignement et de recherche français ou étrangers, des laboratoires publics ou privés. 


\title{
E \\ ESSEC \\ BUSINESS SCHOOL
}

\section{CURRENT ACCOUNT AND REAL EXCHANGE RATE CHANGES: THE IMPACT OF TRADE OPENNESS}

\author{
RESEARCH CENTER \\ ESSEC WORKING PAPER 1520
}

2015

Davide Romelli

Cristina Terra

Enrico Vasconcelos 


\title{
Current Account and Real Exchange Rate changes: the Impact of Trade Openness*
}

\author{
Davide Romelli ${ }^{\dagger}$ \\ Université de Cergy-Pontoise, THEMA and ESSEC Business School \\ Cristina Terra \\ ESSEC Business School and THEMA, 95012 Cergy, France \\ Enrico Vasconcelos \\ Banco Central do Brasil
}

September 29, 2015

\begin{abstract}
This article investigates the impact of trade openness on the relationship between current account and real exchange rates, during episodes of sudden stops and of abrupt exchange rate depreciations. Using data for developed and emerging economies for the period 19702011, we find that more open economies are associated with lower exchange rate depreciations during sudden stops. We also provide evidence that, during abrupt exchange rate depreciation episodes, economies that are more open to trade experience a larger change in current account and trade balance. In other words, our results indicate that improvements in current account and trade balance are accompanied by a smaller exchange rate depreciation in more open economies. These findings are robust to different measures of openness to trade and methodologies of identifying sudden stops and abrupt exchange rate depreciations.
\end{abstract}

Keywords: trade openness; sudden stops; exchange rate depreciation. JEL classification: F31, F32.

\footnotetext{
${ }^{*}$ We would like to thank participants at the $17^{\text {th }}$ Conference Theories and Methods in Macroeconomics, $2^{\text {nd }}$ BPF PhD Camp in HEC Paris, the EABCN Conference on Global Spillovers and Economic Cycles at Banque de France, the $62^{\text {nd }}$ Annual Meeting of the French Economic Association, and seminar participants at Université Paris Sud, for their useful suggestions and comments. Remaining errors are ours.

${ }^{\dagger}$ Corresponding author: davide.romelli@essec.edu.
} 


\section{Introduction}

Advanced and emerging economies alike have experienced a high growth in capital flows over the past twenty years. Throughout the 2000s, this growth was accompanied by large current account imbalances, raising many concerns with respect to the potential adverse consequences of abrupt interruptions of these capital flows. In particular, the magnitude of exchange rate depreciation over the adjustment process of current accounts has been a key element of discussion (Obstfeld and Rogoff, 2005, 2007; Corsetti et al., 2013), reviving the famous debate between John Maynard Keynes and Bertil Ohlin over the payment of war debts in Germany during the 1920s, known as the "Transfer Problem".

In the transfer problem debate, Keynes (1929) argued that, in order to pay for the war damages in foreign currency, Germany would have to raise resources through trade balance surpluses. The relative price of tradable goods would then have to increase, implying a real exchange rate (RER) depreciation. According to Ohlin (1929), however, the decline in Germany's disposable income due to the external payments would entail an increase in trade balance with lesser relative price changes. The mechanism is that, with lower income, the country would buy less of "the goods which go easily between them", using Ohlin's words, thereby improving its trade balance. Clearly, the efficiency of this mechanism depends on the share of those goods in the consumption basket, that is, on the degree of openness of the economy. ${ }^{1}$

The reversion of large current account imbalances brings about a similar adjustment mechanism, where the magnitude of RER depreciations may be mitigated by the income effect, particularly in more open economies. In this paper, we take this adjustment mechanism to the data. More specifically, we ask: are current account reversals achieved with lesser RER depreciation in more open economies?

Clearly, many different variables may affect the relationship between RERs and current accounts, such as changes in the terms of trade or in the relative productivity across sectors and across countries. It would be a daunting, if not an impossible task, to control for all of them. To circumvent this problem, we focus our analysis on episodes of sudden stops in capital flows and of abrupt RER depreciations. In the case of sudden stops, it is reasonable to assume that, on average, other shocks affecting current accounts and RERs would assume a lesser role, so that the observed RER change would be associated to the current account movement. By the same token, in events of abrupt exchange rate depreciation, the corresponding change in current account can be taken as mostly related to the observed

\footnotetext{
${ }^{1}$ This debate has also been related to the experience of Greece during the Eurocrisis in 2011, since its inability to depreciate its currency has impeded a current account reversal.
} 
exchange rate depreciation.

Previous research generally recognizes the importance of openness to trade in determining a country's vulnerability to sudden stops. For example, Calvo et al. (2004) and Cavallo and Frankel (2008) present evidence that more open economies, understood as countries with a larger supply of tradable goods, are less prone to sudden stops in capital flows. The currency crises literature equally stresses the importance of trade openness. Examining the factors that help predict the occurrence of these extreme episodes, Milesi-Ferretti and Razin (2000) find that a higher degree of openness to trade decreases the probability of exchange rate crises. Moreover, they also show how more open economies tend to grow faster in the aftermath of a currency crisis. Similar findings are discussed in Glick and Hutchison (2011), who show that greater trade integration reduces a country's likelihood of experiencing a currency crisis. They argue that a greater openness ratio decreases the likelihood of sharp reversals of capital flows, as the country is more able to service its external obligations.

All in all, this literature has established the importance of trade openness in mitigating a country's vulnerability to sudden stops and currency crises. We take a new perspective by investigating the role of trade openness during these episodes. More specifically, we analyze the role played by trade openness on the relation between current account and RER during sudden stops and abrupt RER depreciation episodes, for both advanced economies and emerging markets.

In a simple theoretical framework, we discuss the mechanism through which trade openness can impact the relationship between current account reversals and RER changes. We model a two-sector small open economy in which sudden stops can occur due to binding collateral constraints on the country's external debt. We show that the effect of sudden stops differs according to the degree of openness of the economy. In particular, more open economies experience a lower exchange rate depreciation, in order to achieve the same change in the current account.

We examine this mechanism for a sample of both advanced and emerging economies during the period 1970-2011. We identify sudden stops and abrupt RER depreciation episodes by following a methodology used in the sudden stops literature. We first show that during sudden stops more open economies endure a lower depreciation of the RER. This motivates our investigation of the impact of trade openness on current account/trade balance reversals during extreme events such as sudden stops and exchange rate depreciations.

We find that trade openness has a positive and significant impact on current account and trade balance variations during these extreme events. This effect is also economically significant. For example, a 1\% RER depreciation in a country with an average degree of openness in our sample is associated with a $2 \%$ increase in current account and a $1.5 \%$ increase in trade balance 
as share of GDP. For a country in the $1^{\text {st }}$ quartile of openness, however, the same variation in the current account and trade balance will require a RER depreciation of more than $11 \%$ and $6.7 \%$, respectively. These results imply that more open economies seem to be able to reach equilibrium in the balance of payments with lesser RER depreciation. Furthermore, these findings are robust to the use of different proxies for openness to trade, as well as different methodologies for identifying episodes of sudden stops and abrupt exchange rate depreciations.

The outline of the paper is as follows. In Section 2 we present a theoretical framework that establishes how openness affects exchange rate depreciation under sudden stops. Section 3 describes the data, while the empirical results are presented in Section 4. Section 5 concludes.

\section{Theoretical Framework}

This section presents a simple theoretical framework that captures the main mechanism highlighted in this paper: in more open economies, lesser RER depreciations are associated with stronger current account reversals. The formal specification of the model follows the small open economy literature with tradable and nontradable goods sectors in the presence of credit constraints (see Mendoza, 2005, 2010; Bianchi, 2011; Korinek and Mendoza, 2013).

Consider an economy populated by a continuum of identical households which receive in every period an endowment of tradable $\left(y_{t}^{T}\right)$ and nontradable $\left(y_{t}^{N}\right)$ goods. They allocate their consumption basket $\left(C_{t}\right)$ between these two goods to maximize their life-time utility function:

$$
U=\sum_{t=0}^{\infty} \beta^{t} u\left(C_{t}\right),
$$

where $\beta$ is the discount factor. For simplicity, we assume Cobb-Douglas preferences, so that:

$$
C_{t}=\left(c_{t}^{T}\right)^{\gamma}\left(c_{t}^{N}\right)^{1-\gamma},
$$

where $\gamma$ is the share of tradable goods in consumption. Households can invest in a foreign asset denominated in units of tradable goods. This asset matures in one period and pays a fixed gross interest rate $R$. Taking the price of tradables as the numeraire and denoting by $p_{t}^{N}$ the price of nontradables, the representative household's budget constraint can be written as:

$$
b_{t+1}+c_{t}^{T}+p_{t}^{N} c_{t}^{N}=y_{t}^{T}+p_{t}^{N} y_{t}^{N}+R b_{t},
$$


where $b_{t+1}$ represents the amount of bonds held by the household at time $t^{2}$

We assume that this economy faces a credit constraint. More specifically, we assume that access to foreign financing is constrained to a fraction $k$ of tradable income. In this case, the credit constraint is represented by:

$$
b_{t+1} \geq-k y_{t}^{T} .
$$

The market clearing condition in the nontradables sector is given by $c_{t}^{N}=y_{t}^{N}$, which we substitute into the budget constraint in equation 3 to rewrite it as:

$$
c_{t}^{T}=y_{t}^{T}+R b_{t}-b_{t+1} .
$$

Our main interest lies in investigating the impact of sudden stops on this small open economy. In line with Mendoza (2005, 2010); Bianchi (2011); Korinek and Mendoza (2013), we model sudden stops as situations in which the international borrowing constraint becomes binding. These events will generate a decrease in tradable goods consumption, a RER depreciation and a current account deficit smaller than desired. Hence, we start by describing the equilibrium when the credit constraint is not binding, and then we compare this with the situation when it is binding. Finally, we show how the effect of a sudden stop differs according to the degree of openness of the economy.

\subsection{Non-binding credit constraint}

Assume that nontradable output is constant over time, $y_{t}^{N}=\bar{y}^{N}$, for all $t$ and that $\beta R=1$. Given these assumptions, when the credit constraint does not bind, the equilibrium simply reflects a perfect consumption smoothing of tradable goods: $c_{t}^{T}=\bar{c}^{T}$ for all $t$. Under a no-Ponzi game condition, the intertemporal budget constraint 5 implies the following constant tradables consumption:

$$
\bar{c}^{T}=\left(\frac{R-1}{R}\right)\left(\sum_{t=0}^{\infty} R^{-t} y_{t}^{T}+R b_{0}\right) .
$$

Consumers maximize utility when the relative price of nontradables is equal to the marginal rate of substitution between the two types of goods:

$$
p_{t}^{N}=\left(\frac{1-\gamma}{\gamma}\right) \frac{c_{t}^{T}}{\bar{c}^{N}} \equiv \bar{p}^{N} .
$$

Note also that the RER $(\varepsilon)$, which is the ratio between the price of tradables and nontradables $\left(\varepsilon_{t}=\frac{1}{p_{t}^{N}}\right)$, is also constant $(\bar{\varepsilon})$ in this unconstrained economy.

\footnotetext{
${ }^{2}$ Here $b$ corresponds to the net international investment position. Notice that debtor countries present a negative value of $b$.
} 
To simplify notation, we follow Mendoza (2005) and define a sequence of time invariant tradables endowment $\bar{y}^{T}$ that yields the same present value of the actual arbitrary time varying sequence of tradables income. We denote this virtual sequence of constant endowment the permanent endowment. According to this definition, tradables consumption under no credit constraints (equation 6) is equal to the permanent endowment, as in:

$$
\bar{c}^{T}=\bar{y}^{T}+(R-1) b_{0},
$$

where $b_{0}$ is the initial net international investment position of the country.

Let us consider a country that is accumulating foreign debt, with a nonbinding credit constraint. In terms of our model, it means that the current endowment of tradables, $y_{t}^{T}$, is smaller that its permanent endowment, $\bar{y}^{T}$. Debt accumulation, which is also the current-account balance, is given by:

$$
b_{t+1}-b_{t}=y_{t}^{T}-\bar{y}^{T}<0 .
$$

At some time in the future, tradables endowment will be higher than its permanent value, in such a way that the country will eventually reimburse its debt.

\subsection{Binding credit constraint: sudden stop episode}

We now analyze the impact of a sudden stop, which is a situation in which the country would be willing to get more indebted but foreign investors are not willing to offer that credit. Sudden stops may be triggered, for instance, by contagion from crises in other countries. We capture this situation in our model by a shock to the credit constraint parameter $k$. This parameter decreases to a new value $k^{S S}$ that renders binding the liquidity constraint 4 , that is, $b_{t+1}<-k^{S S} y_{t}^{T}$. We define as $b_{t+1}^{S S}$ the debt level that satisfies the new liquidity contraint, such that $b_{t+1}^{S S}=-k^{S S} y_{t}^{T}>b_{t+1}$

Under the new credit constraint, consumers are no longer able to completely smooth consumption of tradables. Tradables consumption becomes:

$$
c_{t}^{T, S S}=\left(1+k^{S S}\right) y_{t}^{T}+R b_{t},
$$

which is smaller than the original consumption smoothing plan: $c_{t}^{T, S S}<\bar{c}^{T}$. Moreover, the price of nontradables is now equal to:

$$
p_{t}^{N, S S}=\left(\frac{1-\gamma}{\gamma}\right) \frac{c_{T}^{T, S S}}{\bar{c}^{N}}<\bar{p}^{N},
$$

which means a more depreciated RER: $\varepsilon_{t}^{S S}>\bar{\varepsilon}$.

Notice that, with the binding credit constraint, the current account is also larger than in the case of the unconstrained economy, i.e. $b_{t+1}^{S S}-b_{t}>$ 
$b_{t+1}-b_{t}$, since $b_{t+1}^{S S}>b_{t+1}$. Furthermore, the difference between the two values of the current account is captured by the drop in tradables consumption. From equation 5 , we have that the relation between the drop in consumption and the change in current account is:

$$
\bar{c}^{T}-c_{t}^{T, S S}=\left(b_{t+1}^{S S}-b_{t}\right)-\left(b_{t+1}-b_{t}\right) \equiv \Delta C A>0,
$$

where $\Delta C A$ corresponds to the increase in current-account balance induced by the sudden stop.

In sum, when an unanticipated shock triggers the credit constraint to bind, i.e., when a sudden stop episode occurs, we have that: (i) the consumption of tradable goods decreases, (ii) the real exchange rate depreciates, and (iii) the current account deficit is smaller than it would be under no credit constraint.

\subsection{The role of trade openness}

We define the degree of openness of an economy as the share of tradable goods in consumption, which, given consumers' preferences represented in equation 2, can be expressed as:

$$
\text { Openness }_{t}=\frac{c_{t}^{T}}{p_{t}^{N} \bar{c}^{N}+c_{t}^{T}}=\gamma .
$$

From equation 10, we see that trade openness affects the equilibrium price of nontradables. Substituting the consumption level under sudden stop from equation 12 into the pricing equation 11 and rearranging, we have that:

$$
p_{t}^{N, S S}=\left(\frac{1-\gamma}{\gamma}\right)\left(\frac{\bar{c}^{T}-\Delta C A}{\bar{c}^{N}}\right) .
$$

Equation 14 establishes the relation between the equilibrium price of nontradables and the change in the current-account balance brought about by the sudden stop. According to this equation, the higher the increase in current-account balance (higher $\triangle C A$ ), the lower will be the price of nontradables (more depreciated RER). Moreover, as depicted in the equation, also trade openness affects this relation: in more open economies, there is a smaller price change for a given change in current-account balance.

Going back to the Keynes-Ohlin debate, we could say, in light of this argument, that Ohlin would be right for economies with a high degree of openness. The credit constraint triggered by a sudden stop decreases the disposable income, depressing consumption of both types of goods. Nontradables prices have then to decrease to reestablish equilibrium in the nontradables market. The more open the economy, the larger is the decrease in total tradables consumption and the smaller the decrease in nontradables 
consumption for a given decrease in available income. Hence, the lesser the relative price change.

We investigate whether the data meets this argument: does the relation between current account changes and RER depreciations is affected by trade openness? In order to try and capture the sort of credit constraint shock depicted in our theoretical framework, we investigate the relation between these two variables in events of sudden stops, which are defined as episodes of sudden reversals of capital flows.

As we will explain in detail in the next section, sudden stops are identified as periods in which capital inflow falls by at least two standard deviations below its mean. However, there may be situations in which volatility of capital flows is so high, that an economically significant reversal of capital flow is not identified as a sudden stop. Nevertheless, it would still require current account and RER adjustments. In order to capture those episodes, as an alternative to sudden stop episodes, we investigate events of abrupt exchange rate depreciations.

\section{Event analysis and data}

This section describes how we identify sudden stops and exchange rate depreciation episodes, which are the events on which we base our empirical investigation. We use quarterly data from the IFS-IMF database for a sample of 181 developed and emerging economies for the period 1970-2011. ${ }^{3}$

\subsection{Sudden stops}

We define sudden stops following the methodology implemented by Calvo et al. (2004). We identify an episode as a sudden stop when the year-overyear change in quarterly net capital flows falls two standard deviations below its mean. ${ }^{4}$ As common in the literature, once an episode is identified, we set the beginning of the sudden stop in the first quarter in which the fall in capital flows is larger than one standard deviation below its mean. The episode ends once the fall in net capital flows is smaller than one standard deviation.

\footnotetext{
${ }^{3}$ The list of countries and the period of availability of the data are provided in Appendix Table A1.

${ }^{4}$ In our approach, we follow a large literature that identifies sudden stops as changes in net capital flows. Recent studies on sudden stops are interested in the behavior of different types of gross capital flows and their role in the determination of sudden stops (see Broner et al., 2013; Calderón and Kubota, 2013; Forbes and Warnock, 2012; Rothenberg and Warnock, 2011). Abrupt reversals in these gross capital flows are not necessarily associated with abrupt falls in net capital inflows and are generally due to cross-border bank flows. However, there is no clear evidence that these reversals are associated with real exchange rate depreciations and current account adjustments, which are our main variables of interest.
} 
In line with Calvo et al. (2004), and contrary to other studies (i.e. Guidotti et al., 2004; Edwards, 2004; Calderón and Kubota, 2013), we do not normalize the changes in capital flows by GDP and exclude the episodes for which the shock does not exceed a certain threshold of GDP. By limiting sudden stops to events for which the change in net capital flows exceed a certain threshold (for example Guidotti et al., 2004, fix this threshold at 5\% of GDP), we might exclude episodes that occurred in countries characterized by a low capital flows volatility or less open economies.

Our methodology differs from Calvo et al. (2004) in three main aspects. First, we adapt this methodology to quarterly data and compute the yearover-year changes to avoid seasonal fluctuations. Second, we use three different approaches to computing the average and standard deviation of capital flows. In addition to the historical average used by Calvo et al. (2004), we identify sudden stops by looking at the three/five years moving averages and standard deviations. By limiting the time horizon for the computation of the mean, we are able to detect more accurately "unexpected" reductions in net capital flows. Our baseline specification considers the three year moving average and standard deviation, but we estimate our results using all alternative models. Finally, whenever we identify two sudden stops episodes separated by only one quarter, we consider them as a unique episode.

We proxy the capital inflows $K$ of country $c$ in quarter $q$ as the quarterly change in international reserves $I R$ minus the quarterly current account $C A:^{5}$

$$
K_{c, q}=\left(I R_{c, q}-I R_{c, q-1}\right)-C A_{c, q} .
$$

The year-over-year changes in capital flows are then defined as $\Delta K_{c, q}=$ $K_{c, q}-K_{c, q-4}$. We identify sudden stops whenever the following condition is met:

$$
\Delta K_{c, q}<\mu_{q}\left(\Delta K_{c, q}\right)-2 \sigma_{q}\left(\Delta K_{c, q}\right),
$$

where $\mu_{q}$ and $\sigma_{q}$ represent the three year moving average and standard deviation, respectively in our baseline regressions. We also consider the five year and historical moving averages in alternative specifications.

As an example, the vertical bars in Figure 1 depicts the sudden stop episodes identified for Brazil from 1979 to 2011. The solid line plots $\Delta K_{c, q}$. The values within the dashed lines are up to two standard deviations above and below the three years moving average, while the short dashed lines delimit values within one standard deviation of that average. During this period, Brazil experienced five sudden stops, as highlighted by the vertical bars.

Using this methodology we identify 325 sudden stop episodes for a sample of 105 countries, during the period 1970-2011: 204 of them occurred in

\footnotetext{
${ }^{5}$ All series are measured in constant 2005 dollars.
} 
Figure 1: Sudden stops in Brazil (1979-2011)

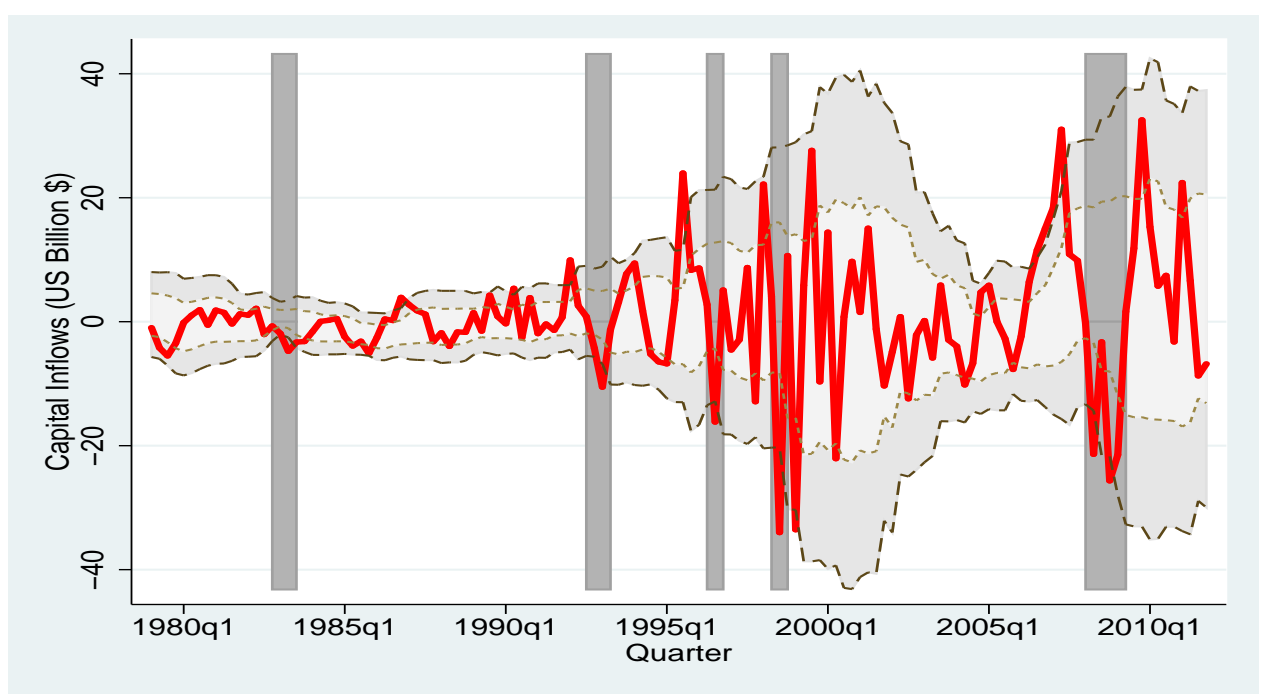

emerging markets and developing countries (as classified by the IMF World Economic Outlook) and 121 in advanced economies. Figure 2 shows the dispersion of sudden stops across countries.

Figure 2: Sudden stop episodes across countries (1970-2011)

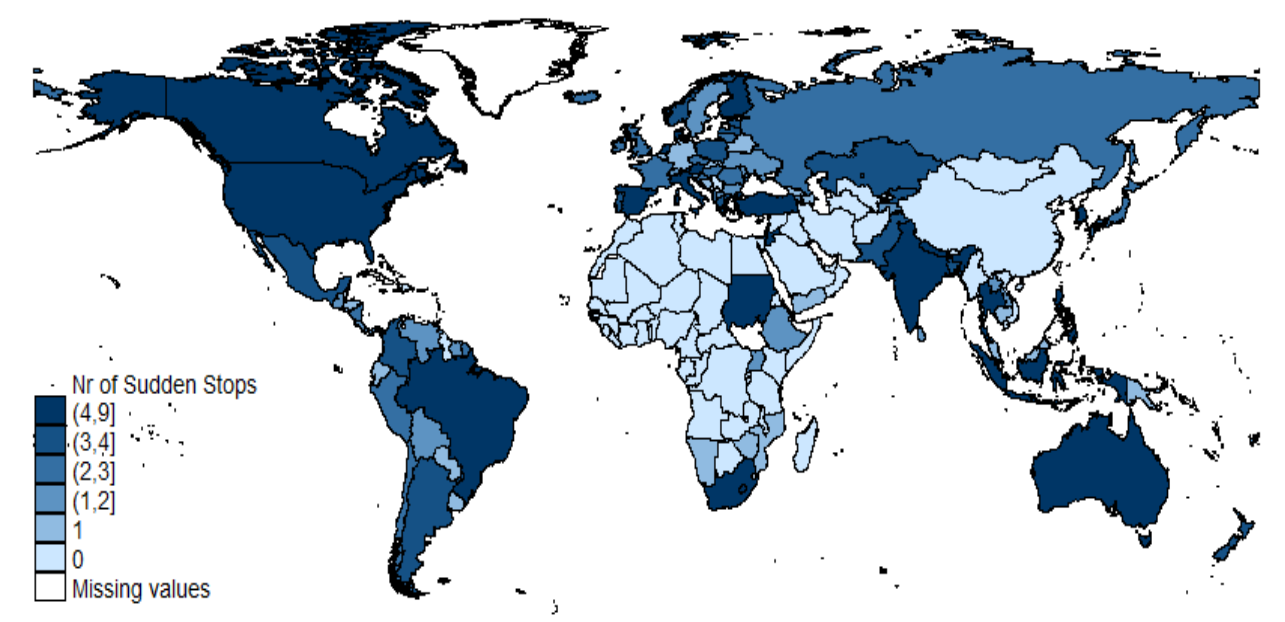

Figure 3 shows the distribution of these events across time. For advanced economies, we observe an increase in sudden stop episodes during the European Monetary System crisis (1990 and 1992) and the Asian crisis (1998). In emerging markets these episodes are concentrated around the Mexican (1994 to 1995), Asian (1997), Russian (1998) and Argentinean (2001) crises. 
Figure 3: Frequency of sudden stops (1970-2011)

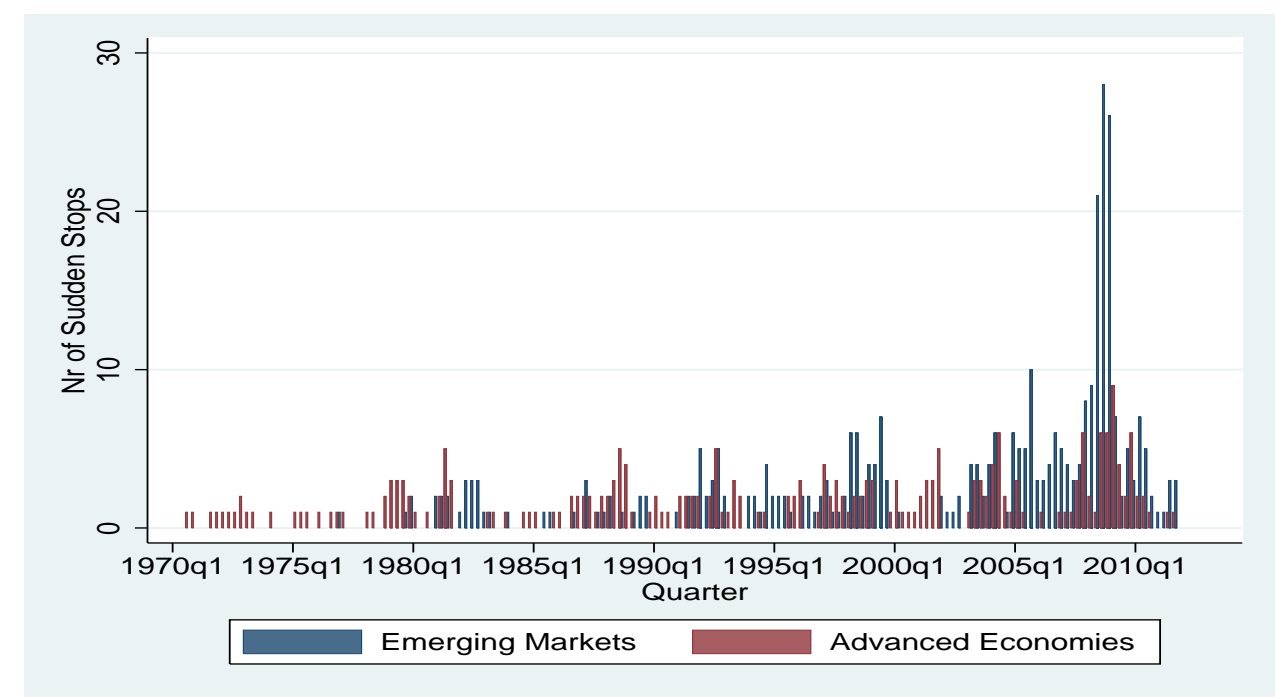

Note that there are missing data for many emerging market economies before the 1990s, which may explain the relatively fewer sudden stops among those countries for the first twenty years of our sample. Looking at the period 1990-2011, we find 157 sudden stops in capital flows among emerging and developing countries and 84 in advanced economies. As expected, these events are much more common in emerging markets. A large number of sudden stops in both emerging and developed economies is detected over the late 2000s, in the midst of the global financial crisis.

Next, we split our sample in terms of their openness to trade (see also Rey and Martin, 2006). We measure trade openness as the average of exports plus imports as a ratio of GDP, over the whole period. We then classify as more open economies those for which the openness ratio is above the median of its group. Figure 4 confirms that more closed economies have experienced a higher number of sudden stops among both advanced economies and emerging markets, in line with the results from Calvo et al. (2004) and Cavallo and Frankel (2008).

\subsection{Episodes of abrupt exchange rate depreciations}

Empirical studies on exchange rate variations commonly focus their attention on nominal exchange rate movements and, more specifically, on currency crises (see, among others, Milesi-Ferretti and Razin, 2000; Laeven and Valencia, 2013). We, in turn, focus on identifying episodes of abrupt RER 
Figure 4: Frequency of sudden stops, by degree of openness (1970-2011)

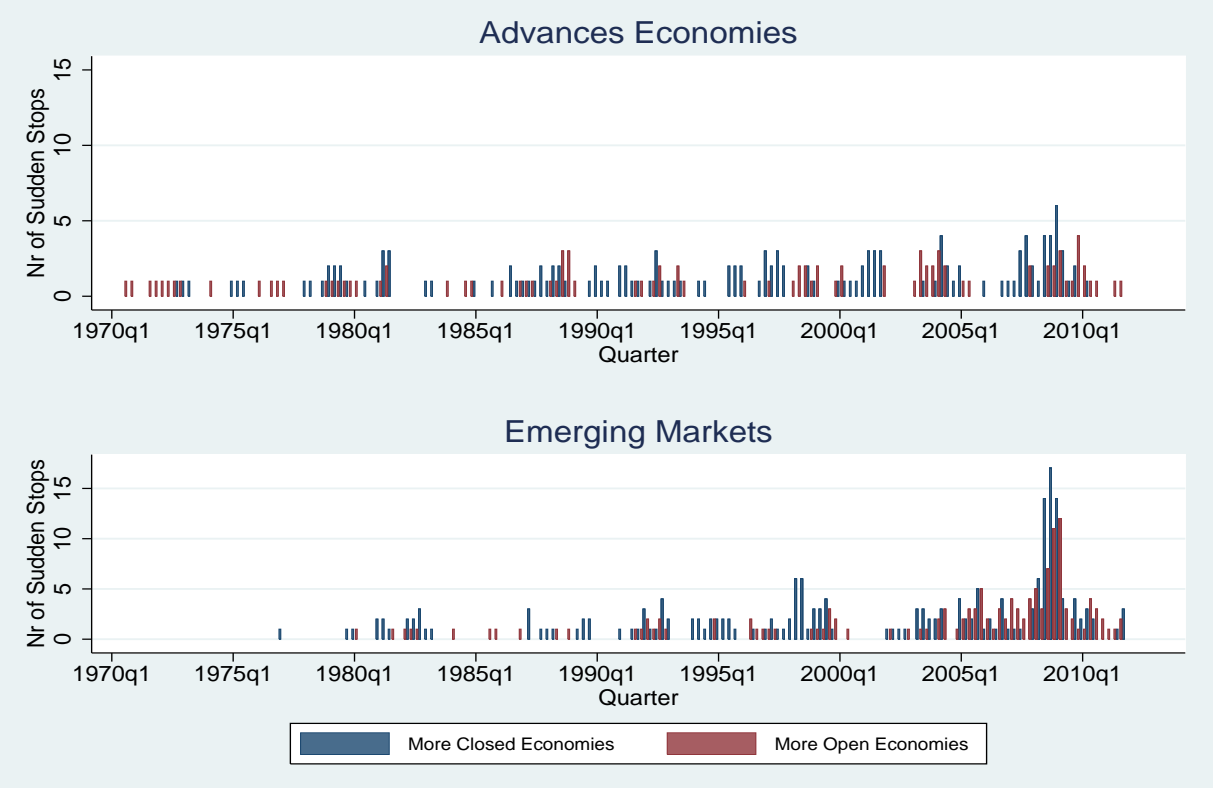

depreciation. ${ }^{6}$

We introduce the concept of abrupt real exchange rate (RER) depreciations, applying to RERs the same methodology used for the identification of sudden stops, described in subsection 3.1. More precisely, an abrupt RER depreciation occurs when the year-over-year depreciation of the quarterly real exchange rate is larger than two standard deviations above its mean. Moreover, the episode window of a RER depreciation: i) begins once the RER depreciation is higher than one standard deviation above its mean; ii) ends when the RER increase falls below one standard deviation of its mean.

We use the real effective exchange rate (REER) as an alternative measure, even if the availability of REER data is restricted to a smaller sample of countries and a shorter period. ${ }^{7}$ We compute episodes of abrupt REER

\footnotetext{
${ }^{6}$ The real exchange rate $\varepsilon$ of country $c$ in quarter $q$ is measured as the nominal exchange exchange rate E, defined as domestic currency per unit of US dollar, multiplied by the ratio between the consumer price index in the US and in country $c$ :

$$
\varepsilon_{c, q}=E_{c, q} * \frac{C P I_{U S, q}}{C P I_{c, q}} .
$$

We then compute the yearly change of the quarterly RER as: $\Delta \varepsilon_{c, q}=\ln \left(\varepsilon_{c, q} / \varepsilon_{c, q-4}\right)$.

${ }^{7}$ The IMF defines the REER as domestic price index divided by foreign price indices, measured in the same currency, so that a decline in its value denotes a real depreciation of the home currency. To facilitate a comparison of the results obtained for REER with
} 
depreciation following the same methodology used for the RER.

Figure 5: $\triangle$ RER and depreciation episodes in Brazil (1981-2011)

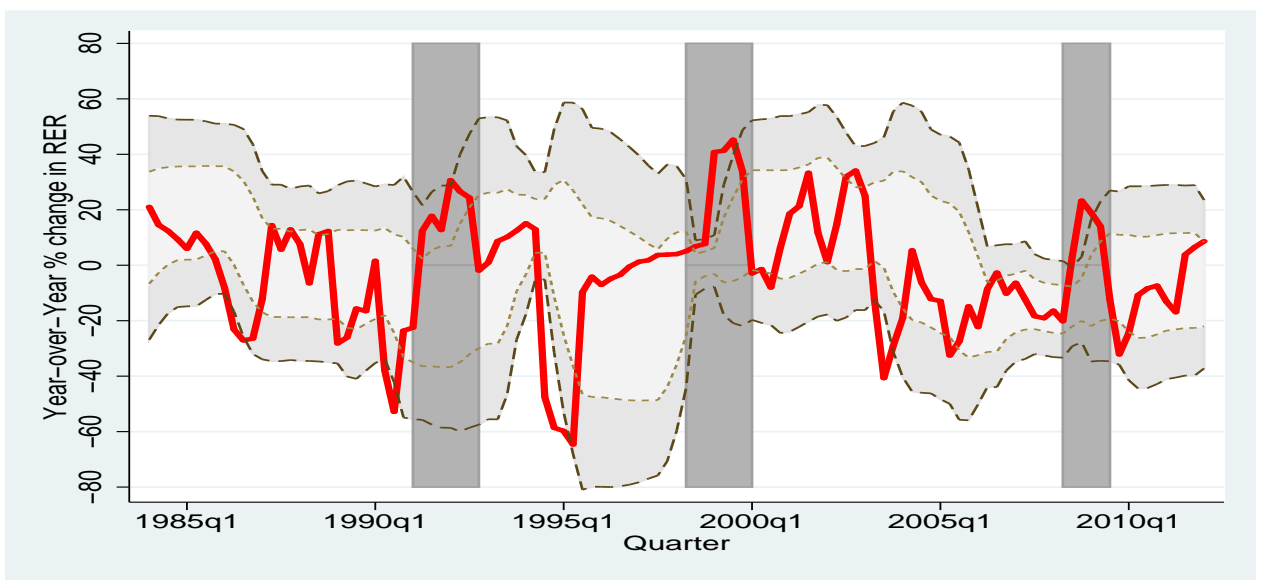

Figures 5 and 6 portray the cases of abrupt RER and REER depreciation episodes identified for Brazil from 1981 to 2011. Similarly to Figure 1 from the previous section, the solid lines plot $\triangle R E R c, q$ and $\triangle R E E R c, q$, while the dashed and short dashed lines depict the intervals of two and one standard deviations from the moving average, respectively. Over the period, Brazil experienced three abrupt RER depreciation episodes and four abrupt REER depreciations, indicated by the vertical bars in Figures 6 and 5 .

Figure 6: $\triangle$ REER and depreciation episodes in Brazil (1981-2011)

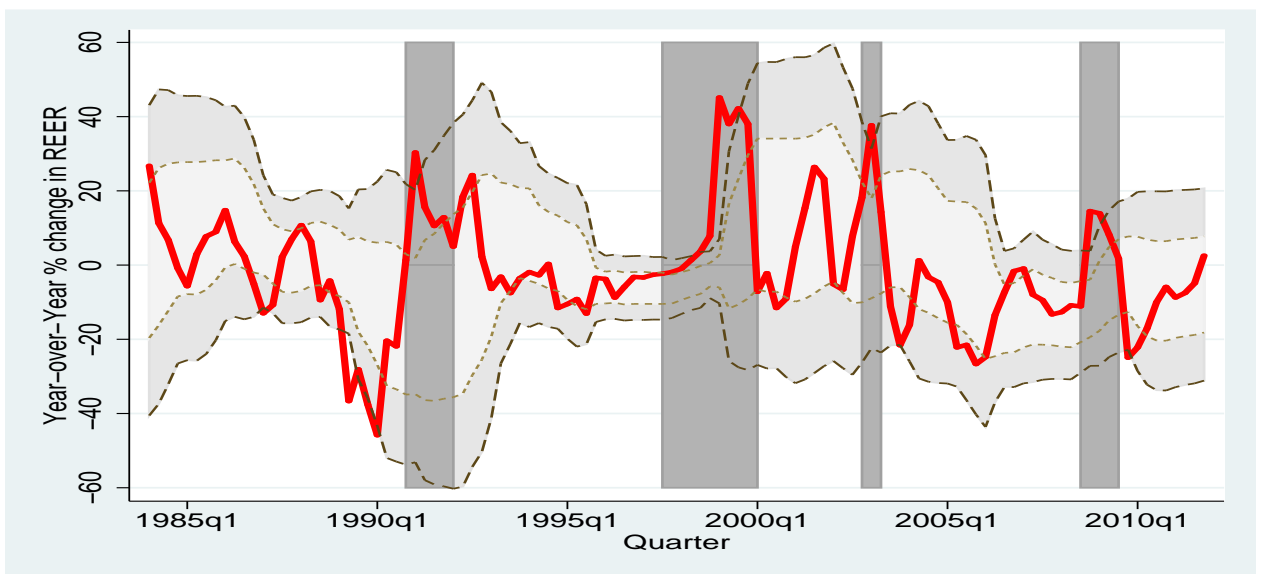

Comparing the two figures, we notice that the real appreciation of the

those of real exchange rates (RER), we compute the year-over-year change of the quarterly $\mathrm{REER}$ as $\triangle R E E R_{c, q}=\ln \left(R E E R_{c, q-4} / R E E R_{c, q}\right)$. Consequently, a positive variation of the REER represents a real depreciation of the home country. 
Brazilian currency between 1994 and 1995, was not followed by an appreciation of the real effective exchange rate. This event could have had a negative impact on the bilateral trade between Brazil and the US and only a marginal effect on the overall values of imports and exports of the country. Apart from that event, the RER and the REER follow similar patterns.

Figure 7: RER depreciation episodes across countries (1970-2011)

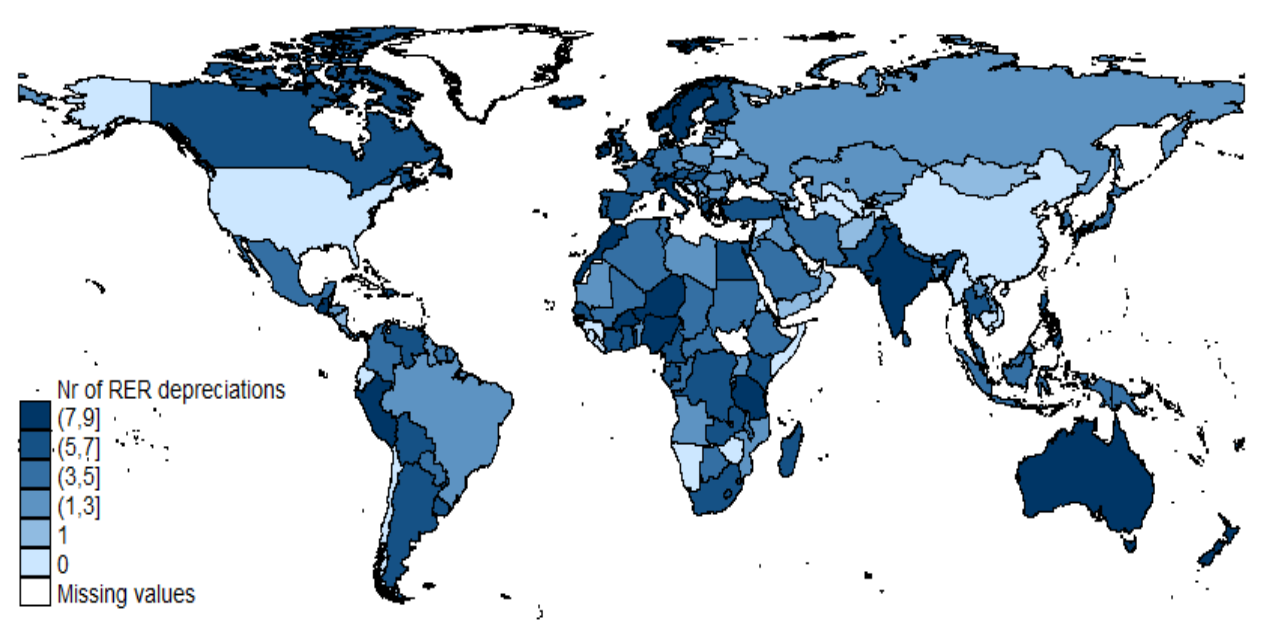

In a broad set of 166 countries, for the period 1970-2011, we find 781 abrupt RER depreciation episodes and 374 for the REER. Figure 7 shows how these episodes are spread across countries, whereas Figure 8 depicts their frequency over time. Comparing the frequency of episodes we see that REER depreciations events are more spread over time (starting from the 1980s) compared to RER depreciations episodes.

The descriptive statistics presented in this section highlight the relatively large frequency of sudden stops and of episodes of abrupt exchange rate depreciations. They also provide motivation for our methodological approach in which we single out these episodes in a cross-section. We turn to describing this methodology next.

\subsection{Event-study analysis}

Our goal is to identify whether the degree of trade openness of a country has an impact on the relationship between current account and exchange rate changes during episodes of sudden stops and of abrupt exchange rate depreciations. To that end, our approach differs from the literature that studies the probability of occurrence of sudden stops, which relies on panel data analysis where these extreme events are captured by a categorical variable. Part of the empirical literature on currency crisis, on its turn, has also 
Figure 8: Frequency of exchange rate depreciation episodes (1970-2011)

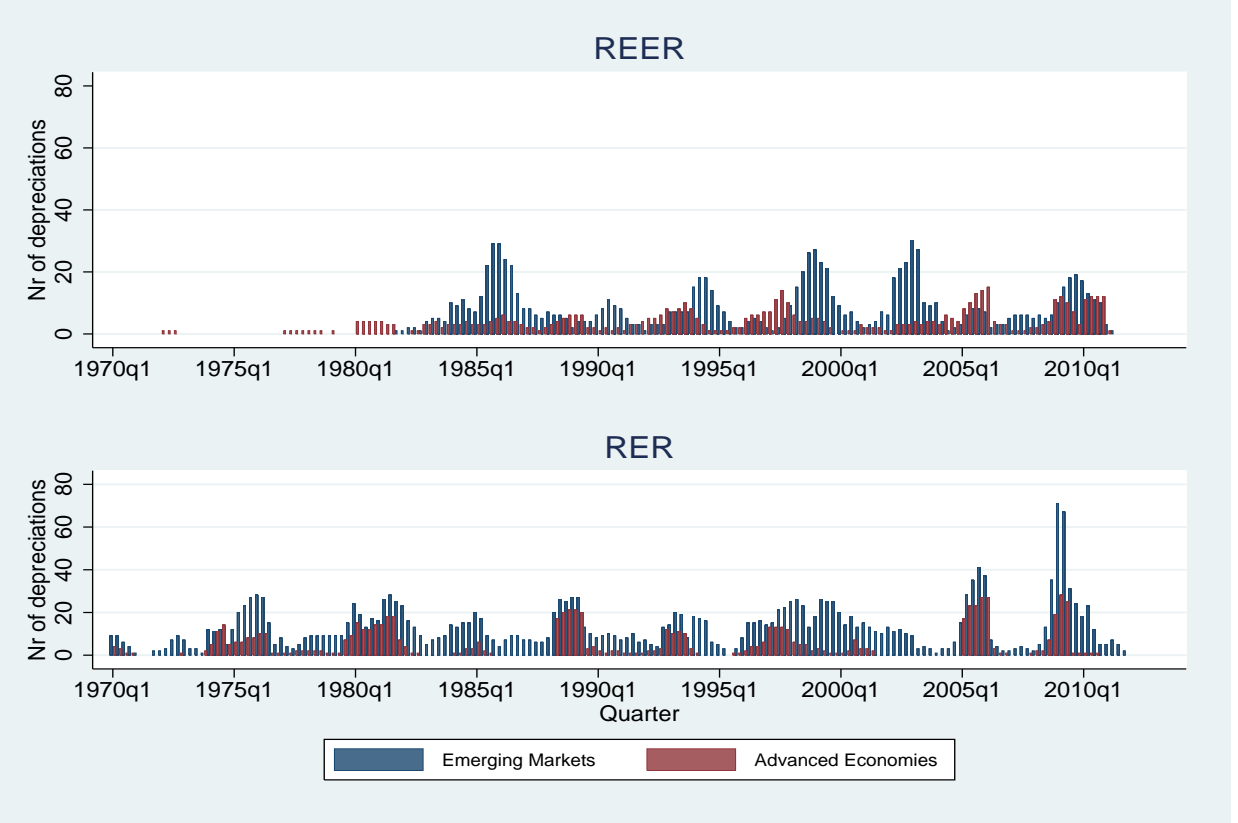

used event-study analysis, such as Eichengreen et al. (1995), Reinhart and Kaminsky (1999) and Gourinchas and Obstfeld (2012).

We implement an event-study analysis in which each of the events identified in sections 3.1 and 3.2 represents one observation. The event-study analysis allows us to circumvent the problem related to the identification of all the variables that might affect the relationship between current account and exchange rate changes. ${ }^{8}$

To avoid transitory movements, we add three quarters to each episode window identified, that is, the episode window is $\left[t_{e b}, t_{e e}+3\right]$, where $t_{e b}$ represents the beginning of an episode and $t_{e e}$ its end. ${ }^{9}$ The pre-episode horizon is, on its turn, defined as $\left[t_{e b-1-n}, t_{e b-1}\right]$, where $n \equiv t_{e e}+3-t_{e b}$, so that it includes the same number of quarters as the episode window. This ensures us that we compute the average value of our key variables over two symmetric periods around a sudden stop or an abrupt exchange rate depreciation.

Using the episode and pre-episode windows as explained in the previous paragraph, we compute the changes in current account and trade balance

\footnotetext{
${ }^{8}$ For discussion on the variables that might affect current account and exchange rate changes see, for example, Calderón and Kubota (2013), Calvo et al. (2004) and MilesiFerretti and Razin (2000).

${ }^{9}$ Recall that an episode ends once the change in the variable of interest bounces back within the range of one standard deviation around its mean.
} 
over GDP, as well as the changes in RER and REER, as the difference in (the log of) their averages over the two symmetric intervals around a shock.

\subsection{Sources of data}

We use quarterly data on exchange rates, current accounts, CPI, imports and exports obtained from the International Monetary Fund's International Financial Statistics (IFS). We compute the changes in these variables following the event study technique previously outlined.

We employ three alternative proxies to compute our main variable of interest, namely, the degree of openness to trade. First, we use a standard measure of openness in the literature, which considers the sum of imports and exports over GDP. This measure, however, is not exactly the definition of openness used in the theoretical model, where we define it as the share of tradables in consumption. Literally, tradable goods should be the sum of all goods that could potentially be exported and the imported goods. We know, however, that there is a big difference between being potentially exported, and being actually exported. For a potentially exportable good to be exported there are non negligible costs involved, and a fast growing literature, particularly after the influential paper of Melitz (2003), certifies that these fixed costs do prevent a large fraction of tradable goods to be actually traded. The tradable goods in the theoretical model refer to "goods which go easily between [the countries]", again, paraphrasing Ohlin. Hence, the sum of imports and exports is a good proxy for this kind of goods.

Furthermore, the toy model in section 2 actually considers the share of tradables in consumption. Thus we employ a second measure of openness defined as the share of imports in total consumption. This measure has been previously employed (see Bussière et al., 2013, for example) and assumes that the domestic economy imports all the tradable goods from abroad and that the degree of openness is given by the ratio between the imported goods and the sum of tradable (imported) and non tradable (domestically produced) goods which can be proxied by the level of aggregate consumption.

Finally, we compute a third measure of openness, which is the ratio of Imports to GDP as in Yanikkaya (2003). Once again, the introduction of this variable as a proxy of openness requires the assumption that the degree of openness in a country is dictated by its imports. It is important to notice that the decision to employ several definitions for openness is driven by the desire to potentially mitigate some of the concerns regarding the difficulty in measuring the degree of trade volumes of a country.

Since the degree of openness to trade might be influenced by the changes in the current account, trade balance and real exchange rates during the episode window of the shocks identified, we need to control for possible endogeneity issues. Our main approach is to look at the lagged value of openness as the average in the year prior to the start of a shock. Our iden- 
tification assumes that past levels of openness are unlikely to be strongly correlated to current changes in the current account or trade balance. Similarly, past levels of openness which are rather stable over short time spans are also not expected to play a strong role in the determination of future quarterly fluctuations in exchange rates. Furthermore, we check the robustness of this method by looking at two- and three-year averages prior to the episode year. ${ }^{10}$

Apart from our main variable of trade openness, we control for other factors that are generally recognized to play an important role in the relationship between the current account and exchange rate changes. These include: terms of trade, world export growth, exchange rate flexibility, government debt to GDP, an index of the original sin and one of financial dollarization. The measure of terms of trade used is the annual Net barter terms of trade index provided by the World Bank, interpolated to obtain quarterly data. However, for a large country in the international goods market, changes in trade balance might impact its terms of trade. Again, to avoid endogeneity problems, we compute the average change in the quarterly terms of trade data in the year before the beginning of each shock.

World real exports growth is computed as the year-over-year change in quarterly exports obtained from the International Monetary Fund's International Financial Statistics (IFS). Similarly to the terms of trade measure, we compute its average value in the year before the beginning of each shock. Next, the degree of exchange rate flexibility is obtained from the exchange rate regime classification developed by Reinhart and Rogoff (2004) and updated by Ilzetzki et al. (2008). An higher value of this measure corresponds to more flexible exchange rate regimes.

The fact that governments in emerging markets cannot finance their debt in domestic currency increases their vulnerability to shocks. ${ }^{11}$ Moreover, in countries characterized by a positive net foreign currency position (foreign currency assets minus foreign currency liabilities), exchange rate depreciations might deteriorate the current account, instead of improving it, due to its impact of the country's debt burden. Hence, we also control for the

\footnotetext{
${ }^{10} \mathrm{An}$ alternative approach to controlling for the endogeneity of openness to trade is an instrumental variable approach, where trade is instrumented by a gravity equation (see Silva and Tenreyro, 2006, among others). While extensively employed in the literature, this measure is of a static nature since it relies on the distances between countries and other geographical specifications to assess the levels of bilateral trade between countries. This undermines the dynamic nature of trade volumes which play a key function in our analysis. Namely, since countries generally experience several episodes of sudden stops or exchange rate depreciations during the analyzed period, the evolution of openness to trade might be able to capture more accurately the importance of gradually opening ones economy to trade during these extreme episodes.

${ }^{11}$ Tovar (2005) documents that, in Latin America, around two fifths of government bonds have been issued internationally, and virtually none of this is denominated in local currency.
} 
degree of financial dollarization of the country.

More precisely, we add the following explanatory variables: the ratio of government debt over GDP, an index of the original sin and an index of financial dollarization. The gross government debt-to-GDP ratio is obtained from Abbas et al. (2010). Following Hausmann and Panizza (2003), we compute the original sin index (OSIN) of a country as one minus the share of the stock of international securities issued by the country in its own currency. Data for computing the index have been obtained from Fitch Ratings. Finally, the index of financial dollarization has been obtained from Levy Yeyati (2006), who uses data on official credit, cross-border loans, external private and public bonded debt and domestic deposits, to compute the degree of financial dollarization of a country. For all of these three measures, we use their values in the year before the beginning of each episode.

\section{Empirical results}

We now investigate the impact of trade openness on changes in current account and real exchange rate, as established by equation 14 from our theoretical framework. Notice that the equation establishes the relation between relative prices and changes in current account, but it does not imply causality. In our economy, a liquidity shock generates a change in relative prices so as to achieve the level of tradables consumption compatible with the new current-account balance. Both the current account and the RER are determined simultaneously by the equilibrium conditions of the model.

In the real world, however, other shocks to the economy that affect the exchange rate may occur simultaneously to capital reversals, such as government interventions in the foreign currency market. The exchange rate change, in turn, has an impact on the current account. Hence, reverse causality would be an issue were we use the real exchange rate as the dependent variable in our regressions. For this reason, we look at this question from the opposite perspective, namely, we investigate whether current account reversals are stronger in more open economies, after controlling for RER changes.

We first examine the impact of openness to trade on the relationship between current account and exchange rate changes during episodes of sudden stops. We then consider the same empirical exercise when looking at episodes of abrupt RER and REER depreciations.

\subsection{Openness, current account reversals and exchange rates during sudden stops}

We first investigate the link between current account/trade balance adjustments, trade openness and exchange rates and during episodes of sudden stops in capital inflows. In this event-study analysis, some countries may 
appear more than once if they suffer more than one sudden stop over the time span of our study. Therefore, in all our regressions we relax the assumption of independently distributed error terms across time, allowing the clustering of observations by country. We assume instead that the error term is i.i.d. across countries, but not necessarily so for different observations for the same economy. All reported standard errors are adjusted for clustering.

We check whether openness affects the current account, after controlling for the changes in both RER or REER. We present the results pertaining to RER changes in Table 1. More specifically, Columns (1), (6) and (11) present our baseline regression for each different measure of trade openness employed. We find that the coefficient of openness to trade is always positive and statistically significant across all specifications. This confirms our main hypothesis that, during sudden stop episodes, countries more open to trade experience a larger change in current account to GDP for the same level of real exchange rate depreciation. At the same time, $\triangle \mathrm{RER}$ is also positive and statistically significant in this baseline estimation, in line with intuition.

Our main result is also also robust to the inclusion of other relevant control variables which can influence the current-account adjustment, such as changes in terms of trade, world exports growth, exchange rate regime and external debt proxies. The coefficient of terms of trade is positive and statistically significant across most specifications, suggesting that improvements in the terms of trade can stimulate current-account reversals. World export growth is generally not significant in these estimations. The same goes for our controls for the level of countries' external indebtedness. The exchange rate regime dummy is negative and significant in most cases, suggesting that economies with less flexible exchange rate regimes might experience higher changes in the current account over GDP when facing a sudden stop.

Finally, we add a dummy variable for emerging markets to capture possible differences between developed and emerging economies. These two types of economies differ in a number of ways, including the level of external debt, risk, trade patterns, among others, which could potentially affect how their current accounts respond to exchange rate changes. We also control for time fixed effects with three decade dummies, for the 1970s, 1980s and 1990s. Results are consistent with the inclusion of these additional robustness checks.

We obtain similar results when controlling for the changes in REER as opposed to RER. We present these estimations in Appendix Table A2. The coefficient of openness to trade is also positive and highly statistically significant across all definitions of openness. Similar to the RER estimations, the changes in REER also have a positive impact on current-account variations, although the coefficient is not very precisely estimated in all specifications. These results are, again, robust to the inclusion of the same set of control variables. 
Table 1: Current account and openness during sudden stops

\begin{tabular}{|c|c|c|c|c|c|c|c|c|c|c|c|c|c|c|c|}
\hline & (1) & (2) & (3) & (4) & (5) & (6) & (7) & (8) & (9) & (10) & (11) & $(12)$ & (13) & (14) & (15) \\
\hline Openness1 & $\begin{array}{c}0.0240^{* *} \\
(0.010)\end{array}$ & $\begin{array}{c}0.0205^{*} \\
(0.012)\end{array}$ & $\begin{array}{l}0.0231^{*} \\
(0.012)\end{array}$ & $\begin{array}{l}0.0238 \\
(0.018)\end{array}$ & $\begin{array}{c}0.0806^{* * *} \\
(0.017)\end{array}$ & & & & & & & & & & \\
\hline Openness2 & & & & & & $\begin{array}{c}0.0506^{* * *} \\
(0.015)\end{array}$ & $\begin{array}{c}0.0692 * * * \\
(0.023)\end{array}$ & $\begin{array}{c}0.0532 * * * \\
(0.019)\end{array}$ & $\begin{array}{c}0.0662 * * * \\
(0.020)\end{array}$ & $\begin{array}{c}0.0983^{* * *} \\
(0.028)\end{array}$ & & & & & \\
\hline Openness3 & & & & & & & & & & & $\begin{array}{c}0.0526^{* * *} \\
(0.017)\end{array}$ & $\begin{array}{l}0.0421^{*} \\
(0.021)\end{array}$ & $\begin{array}{c}0.0482^{* *} \\
(0.021)\end{array}$ & $\begin{array}{l}0.0449 \\
(0.037)\end{array}$ & $\begin{array}{c}0.1235^{* * *} \\
(0.028)\end{array}$ \\
\hline$\Delta$ RER & $\begin{array}{c}0.0473^{* *} \\
(0.022)\end{array}$ & $\begin{array}{l}0.0416 \\
(0.033)\end{array}$ & $\begin{array}{l}0.0330 \\
(0.032)\end{array}$ & $\begin{array}{l}0.0055 \\
(0.042)\end{array}$ & $\begin{array}{l}0.0556 \\
(0.045)\end{array}$ & $\begin{array}{c}0.0532^{* *} \\
(0.022)\end{array}$ & $\begin{array}{l}0.0520 \\
(0.038)\end{array}$ & $\begin{array}{l}0.0448 \\
(0.040)\end{array}$ & $\begin{array}{l}0.0221 \\
(0.043)\end{array}$ & $\begin{array}{l}0.0490 \\
(0.046)\end{array}$ & $\begin{array}{c}0.0471^{* *} \\
(0.021)\end{array}$ & $\begin{array}{l}0.0362 \\
(0.032)\end{array}$ & $\begin{array}{l}0.0271 \\
(0.031)\end{array}$ & $\begin{array}{l}0.0000 \\
(0.043)\end{array}$ & $\begin{array}{l}0.0484 \\
(0.043)\end{array}$ \\
\hline $\begin{array}{l}\text { Control Variables: } \\
\Delta \text { Terms of Trade }\end{array}$ & & $\begin{array}{c}0.1202^{* * * *} \\
(0.044)\end{array}$ & $\begin{array}{c}0.1292^{* *} \\
(0.051)\end{array}$ & $\begin{array}{l}0.0699 \\
(0.051)\end{array}$ & $\begin{array}{c}0.1394^{* * *} \\
(0.050)\end{array}$ & & $\begin{array}{c}0.0870^{* *} \\
(0.034)\end{array}$ & $\begin{array}{c}0.0653^{*} \\
(0.039)\end{array}$ & $\begin{array}{l}0.0561 \\
(0.036)\end{array}$ & $\begin{array}{c}0.1082^{* *} \\
(0.044)\end{array}$ & & $\begin{array}{c}0.0957^{* *} \\
(0.046)\end{array}$ & $\begin{array}{c}0.1046^{* *} \\
(0.051)\end{array}$ & $\begin{array}{l}0.0380 \\
(0.059)\end{array}$ & $\begin{array}{c}0.1588^{* * * *} \\
(0.045)\end{array}$ \\
\hline World Real Export Growth & & $\begin{array}{l}0.0300 \\
(0.026)\end{array}$ & $\begin{array}{l}0.0186 \\
(0.025)\end{array}$ & $\begin{array}{l}0.0389 \\
(0.027)\end{array}$ & $\begin{array}{l}-0.0106 \\
(0.043)\end{array}$ & & $\begin{array}{l}0.0126 \\
(0.025)\end{array}$ & $\begin{array}{l}-0.0032 \\
(0.023)\end{array}$ & $\begin{array}{l}-0.0021 \\
(0.022)\end{array}$ & $\begin{array}{l}-0.0353 \\
(0.042)\end{array}$ & & $\begin{array}{l}0.0095 \\
(0.029)\end{array}$ & $\begin{array}{r}-0.0042 \\
(0.029)\end{array}$ & $\begin{array}{l}0.0114 \\
(0.034)\end{array}$ & $\begin{array}{l}-0.0099 \\
(0.041)\end{array}$ \\
\hline IMF Emerging Mkt Dummy & & $\begin{array}{r}-0.0015 \\
(0.006)\end{array}$ & $\begin{array}{l}-0.0013 \\
(0.006)\end{array}$ & $\begin{array}{l}0.0041 \\
(0.011)\end{array}$ & $\begin{array}{l}0.0190 \\
(0.013)\end{array}$ & & $\begin{array}{c}-0.0012 \\
(0.008)\end{array}$ & $\begin{array}{l}-0.0027 \\
(0.007)\end{array}$ & $\begin{array}{l}0.0191^{*} \\
(0.011)\end{array}$ & $\begin{array}{l}0.0251^{*} \\
(0.013)\end{array}$ & & $\begin{array}{l}-0.0015 \\
(0.006)\end{array}$ & $\begin{array}{r}-0.0016 \\
(0.006)\end{array}$ & $\begin{array}{l}0.0070 \\
(0.011)\end{array}$ & $\begin{array}{l}0.0106 \\
(0.012)\end{array}$ \\
\hline Exchange Rate Regime & & $\begin{array}{l}-0.0057^{* *} \\
(0.003)\end{array}$ & & & & & $\begin{array}{l}0.0041 \\
(0.004)\end{array}$ & & & & & $\begin{array}{c}-0.0053^{*} \\
(0.003)\end{array}$ & & & \\
\hline Debt/GDP & & & $\begin{array}{l}-0.0002 \\
(0.000)\end{array}$ & & & & & $\begin{array}{l}-0.0002 \\
(0.000)\end{array}$ & & & & & $\begin{array}{c}-0.0002^{*} \\
(0.000)\end{array}$ & & \\
\hline Original Sin & & & & $\begin{array}{l}0.0329 \\
(0.044)\end{array}$ & & & & & $\begin{array}{c}0.0948^{* *} \\
(0.042)\end{array}$ & & & & & $\begin{array}{l}0.0376 \\
(0.043)\end{array}$ & \\
\hline Financial Dollarization & & & & & $\begin{array}{l}0.0007 \\
(0.001)\end{array}$ & & & & & $\begin{array}{l}-0.0001 \\
(0.001)\end{array}$ & & & & & $\begin{array}{l}0.0005 \\
(0.001)\end{array}$ \\
\hline Observations & 285 & 177 & 178 & 124 & 104 & 195 & 120 & 119 & 98 & 72 & 285 & 178 & 179 & 125 & 104 \\
\hline Nr. of countries & 87 & 79 & 81 & 64 & 47 & 57 & 54 & 54 & 52 & 34 & 88 & 80 & 82 & 65 & 47 \\
\hline R-squared & 0.051 & 0.087 & 0.086 & 0.040 & 0.176 & 0.093 & 0.107 & 0.110 & 0.119 & 0.138 & 0.076 & 0.087 & 0.092 & 0.035 & 0.178 \\
\hline
\end{tabular}

Openness1 is measured as the ratio of exports plus imports to GDP Openness2 as the share imports in total consumption, while Openness 3 is the ratio of imports to GDP. Decades dummies (except

in Columns (1), (6) and (11)) and a constant term are included but not reported. Robust standard errors in parentheses. $* * * \mathrm{p}<0.01, * * \mathrm{p}<0.05, * \mathrm{p}<0.1$. 
Table 2: Trade balance and openness during sudden stops

Dependent variable: Changes in trade balance/GDP

\begin{tabular}{|c|c|c|c|c|c|c|c|c|c|c|c|c|c|c|c|}
\hline & $\overline{(1)}$ & 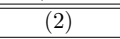 & (3) & $\overline{(4)}$ & (5) & $\overline{(6)}$ & $\overline{(7)}$ & $\overline{(8)}$ & $\overline{(9)}$ & 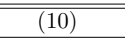 & $\overline{~(11)}$ & 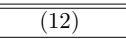 & 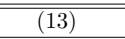 & (14) & $\overline{~(15)}$ \\
\hline Openness1 & $\begin{array}{c}0.0263^{* *} \\
(0.011)\end{array}$ & $\begin{array}{l}0.0227^{*} \\
(0.012)\end{array}$ & $\begin{array}{l}0.0224^{*} \\
(0.012)\end{array}$ & $\begin{array}{l}0.0153 \\
(0.015)\end{array}$ & $\begin{array}{c}0.0753^{* * *} \\
(0.016)\end{array}$ & & & & & & & & & & \\
\hline Openness2 & & & & & & $\begin{array}{c}0.0323 * * \\
(0.015)\end{array}$ & $\begin{array}{c}0.0608^{* * *} \\
(0.022)\end{array}$ & $\begin{array}{c}0.0469^{* *} \\
(0.020)\end{array}$ & $\begin{array}{c}0.0594^{* * *} \\
(0.021)\end{array}$ & $\begin{array}{c}0.0949^{* * *} \\
(0.031)\end{array}$ & & & & & \\
\hline Openness3 & & & & & & & & & & & $\begin{array}{c}0.0556^{* * *} \\
(0.019)\end{array}$ & $\begin{array}{c}0.0552^{* *} \\
(0.023)\end{array}$ & $\begin{array}{c}0.0518^{* *} \\
(0.022)\end{array}$ & $\begin{array}{l}0.0304 \\
(0.028)\end{array}$ & $\begin{array}{c}0.1105^{* * * *} \\
(0.028)\end{array}$ \\
\hline$\Delta$ RER & $\begin{array}{c}0.0917^{* * *} \\
(0.032)\end{array}$ & $\begin{array}{l}0.1054^{*} \\
(0.056)\end{array}$ & $\begin{array}{l}0.0961^{*} \\
(0.055)\end{array}$ & $\begin{array}{l}0.0327 \\
(0.040)\end{array}$ & $\begin{array}{l}0.1108 \\
(0.084)\end{array}$ & $\begin{array}{l}0.0678^{*} \\
(0.035)\end{array}$ & $\begin{array}{l}0.0851 \\
(0.066)\end{array}$ & $\begin{array}{l}0.0790 \\
(0.066)\end{array}$ & $\begin{array}{l}0.0209 \\
(0.038)\end{array}$ & $\begin{array}{l}0.0885 \\
(0.086)\end{array}$ & $\begin{array}{c}0.0899^{* * * *} \\
(0.033)\end{array}$ & $\begin{array}{l}0.1052^{*} \\
(0.055)\end{array}$ & $\begin{array}{c}0.0965^{*} \\
(0.055)\end{array}$ & $\begin{array}{l}0.0331 \\
(0.040)\end{array}$ & $\begin{array}{l}0.1040 \\
(0.081)\end{array}$ \\
\hline $\begin{array}{l}\text { Control Variables: } \\
\Delta \text { Terms of Trade }\end{array}$ & & $\begin{array}{c}0.2707^{* * *} \\
(0.070)\end{array}$ & $\begin{array}{c}0.2474^{* * *} \\
(0.066)\end{array}$ & $\begin{array}{c}0.2209^{* * *} \\
(0.081)\end{array}$ & $\begin{array}{c}0.2568 * * * \\
(0.081)\end{array}$ & & $\begin{array}{c}0.2500^{* * *} \\
(0.083)\end{array}$ & $\begin{array}{c}0.2241^{* * *} \\
(0.079)\end{array}$ & $\begin{array}{c}0.2138^{* * *} \\
(0.078)\end{array}$ & $\begin{array}{c}0.3097 * * * \\
(0.105)\end{array}$ & & $\begin{array}{c}0.2797^{* * *} \\
(0.070)\end{array}$ & $\begin{array}{c}0.2540^{* * *} \\
(0.066)\end{array}$ & $\begin{array}{c}0.2280^{* * *} \\
(0.080)\end{array}$ & $\begin{array}{c}0.2778 * * * \\
(0.089)\end{array}$ \\
\hline World Real Export Growth & & $\begin{array}{l}0.0498 \\
(0.032)\end{array}$ & $\begin{array}{l}0.0384 \\
(0.031)\end{array}$ & $\begin{array}{c}0.0636^{* * *} \\
(0.024)\end{array}$ & $\begin{array}{l}0.0164 \\
(0.059)\end{array}$ & & $\begin{array}{l}0.0441^{*} \\
(0.023)\end{array}$ & $\begin{array}{l}0.0209 \\
(0.021)\end{array}$ & $\begin{array}{l}0.0317 \\
(0.020)\end{array}$ & $\begin{array}{l}-0.0169 \\
(0.057)\end{array}$ & & $\begin{array}{l}0.0489 \\
(0.033)\end{array}$ & $\begin{array}{l}0.0375 \\
(0.031)\end{array}$ & $\begin{array}{c}0.0637^{* * *} \\
(0.024)\end{array}$ & $\begin{array}{l}0.0179 \\
(0.055)\end{array}$ \\
\hline IMF Emerging Mkt Dummy & & $\begin{array}{l}-0.0060 \\
(0.007)\end{array}$ & $\begin{array}{r}-0.0049 \\
(0.007)\end{array}$ & $\begin{array}{l}-0.0060 \\
(0.011)\end{array}$ & $\begin{array}{l}0.0090 \\
(0.011)\end{array}$ & & $\begin{array}{l}-0.0079 \\
(0.007)\end{array}$ & $\begin{array}{l}-0.0099 \\
(0.007)\end{array}$ & $\begin{array}{l}0.0082 \\
(0.011)\end{array}$ & $\begin{array}{l}0.0079 \\
(0.013)\end{array}$ & & $\begin{array}{l}-0.0095 \\
(0.007)\end{array}$ & $\begin{array}{l}-0.0079 \\
(0.007)\end{array}$ & $\begin{array}{l}-0.0063 \\
(0.010)\end{array}$ & $\begin{array}{l}0.0002 \\
(0.010)\end{array}$ \\
\hline Exchange Rate Regime & & $\begin{array}{c}-0.0066^{* *} \\
(0.003)\end{array}$ & & & & & $\begin{array}{l}0.0015 \\
(0.003)\end{array}$ & & & & & $\begin{array}{c}-0.0051^{*} \\
(0.003)\end{array}$ & & & \\
\hline Debt/GDP & & & $\begin{array}{c}-0.0002 \\
(0.000)\end{array}$ & & & & & $\begin{array}{l}-0.0003 \\
(0.000)\end{array}$ & & & & & $\begin{array}{c}-0.0002 \\
(0.000)\end{array}$ & & \\
\hline Original Sin & & & & $\begin{array}{l}0.0087 \\
(0.048)\end{array}$ & & & & & $\begin{array}{l}0.0757 \\
(0.046)\end{array}$ & & & & & $\begin{array}{l}0.0132 \\
(0.049)\end{array}$ & \\
\hline Financial Dollarization & & & & & $\begin{array}{l}0.0008 \\
(0.001)\end{array}$ & & & & & $\begin{array}{l}0.0006 \\
(0.001)\end{array}$ & & & & & $\begin{array}{l}0.0007 \\
(0.001)\end{array}$ \\
\hline Observations & 287 & 179 & 179 & 125 & 105 & 195 & 120 & 119 & 98 & 72 & 285 & 179 & 179 & 125 & 105 \\
\hline Nr. of countries & 89 & 80 & 81 & 64 & 48 & 57 & 54 & 54 & 52 & 34 & 89 & 80 & 81 & 64 & 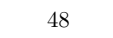 \\
\hline R-squared & 0.058 & 0.156 & 0.133 & 0.114 & 0.178 & 0.055 & 0.143 & 0.153 & 0.197 & 0.177 & 0.074 & 0.172 & 0.149 & 0.115 & 0.173 \\
\hline
\end{tabular}

wile Openness 3 is the ratio of imports to GDP. Decades dum

in Columns (1), (6) and (11)) and a constant term are included but not reported. Robust standard errors in parentheses. ${ }^{* * *} \mathrm{p}<0.01,{ }^{* *} \mathrm{p}<0.05,{ }^{*} \mathrm{p}<0.1$. 
Trade balance is an important part of the current account, and currentaccount reversals are achieved mainly through improvements in the trade balance. We thus re-do the empirical investigation using trade balance as dependent variable. The results, presented in Table 2 are qualitatively similar and support our main hypothesis. Furthermore, when controlling for the same additional determinants of trade, we obtain the similar results. Yet, while we note no relevant differences in the ability of openness to impact changes in current account or in trade balance, we do observe that exchange rate changes seem to have a stronger impact on trade balance compared to current account changes. This suggests that the mechanism our estimations capture is mainly obtained through adjustments in trade balance. Again, we check the robustness of these results when controlling for changes in real effective exchange rates as compared to RER. These additional findings are presented in Appendix Table A3 and are qualitatively the same.

Overall, our results show that, during sudden stops, countries more open to trade experience a higher improvement in current account and trade balance, controlling for exchange rate changes. In other words, to achieve the same level of current account or trade balance improvement, a more open economy endures a smaller exchange rate depreciation. This effect is also economically significant. In our sample, the degree of openness to trade varies significantly across countries, with a mean of $64 \%$ and a standard deviation of $44 \%$. Given the coefficients presented in column (1) of Tables A2 and A3, a country with a degree of openness equal to the mean will have to depreciate its currency by less than $1 \%$ in order to obtain an increase of its current account over GDP equal to $2 \%$ ( $1.5 \%$ for the case of trade balance). For countries with a lower degree of openness, say, equal to the $1^{\text {st }}$ quartile (37\%), a real exchange rate depreciation of more than $11 \%$ is needed in order to obtain the same variation in the current account, and of more than $6.7 \%$ for the same change in the trade balance. 
Table 3: Current account and openness during RER depreciation episodes

\begin{tabular}{|c|c|c|c|c|c|c|c|c|c|c|c|c|c|c|c|}
\hline & (1) & (2) & $\overline{(3)}$ & (4) & (5) & 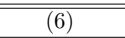 & (7) & 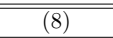 & (9) & $(10)$ & (11) & $(12)$ & (13) & (14) & $(15)$ \\
\hline Openness1 & $\begin{array}{c}0.0244^{* * * *} \\
(0.006)\end{array}$ & $\begin{array}{c}0.0255^{* * *} \\
(0.008)\end{array}$ & $\begin{array}{c}0.0269 * * * \\
(0.007)\end{array}$ & $\begin{array}{c}0.0336^{* *} \\
(0.014)\end{array}$ & $\begin{array}{c}0.0850^{* * *} \\
(0.022)\end{array}$ & & & & & & & & & & \\
\hline Openness2 & & & & & & $\begin{array}{c}0.0618^{* * *} \\
(0.022)\end{array}$ & $\begin{array}{c}0.0841^{* * *} \\
(0.031)\end{array}$ & $\begin{array}{c}0.0756^{* * *} \\
(0.029)\end{array}$ & $\begin{array}{c}0.0711^{* *} \\
(0.032)\end{array}$ & $\begin{array}{c}0.1600 * * * \\
(0.044)\end{array}$ & & & & & \\
\hline Openness3 & & & & & & & & & & & $\begin{array}{c}0.0580^{* * *} \\
(0.014)\end{array}$ & $\begin{array}{c}0.0557^{* * * *} \\
(0.016)\end{array}$ & $\begin{array}{c}0.0588^{* * *} \\
(0.014)\end{array}$ & $\begin{array}{c}0.0817^{* * *} \\
(0.029)\end{array}$ & $\begin{array}{c}0.1590^{* * * *} \\
(0.039)\end{array}$ \\
\hline$\Delta \mathrm{RER}$ & $\begin{array}{c}0.0533^{* *} \\
(0.020)\end{array}$ & $\begin{array}{c}0.0769^{* *} \\
(0.030)\end{array}$ & $\begin{array}{c}0.0709 * * * \\
(0.025)\end{array}$ & $\begin{array}{c}0.0632^{* *} \\
(0.031)\end{array}$ & $\begin{array}{c}0.0891^{* * *} \\
(0.024)\end{array}$ & $\begin{array}{c}0.0601 * * \\
(0.025)\end{array}$ & $\begin{array}{l}0.0636^{*} \\
(0.037)\end{array}$ & $\begin{array}{c}0.0637^{* *} \\
(0.029)\end{array}$ & $\begin{array}{c}0.0607^{*} \\
(0.035)\end{array}$ & $\begin{array}{l}0.0636^{*} \\
(0.037)\end{array}$ & $\begin{array}{c}0.0589^{* * * *} \\
(0.020)\end{array}$ & $\begin{array}{c}0.0766^{* *} \\
(0.030)\end{array}$ & $\begin{array}{c}0.0745^{* * * *} \\
(0.025)\end{array}$ & $\begin{array}{c}0.0664^{* *} \\
(0.029)\end{array}$ & $\begin{array}{c}0.0985^{* * *} \\
(0.024)\end{array}$ \\
\hline Control Variables: & & & & & & & & & & & & & & & \\
\hline$\Delta$ Terms of Trade & & $\begin{array}{c}0.0939 * * \\
(0.045)\end{array}$ & $\begin{array}{l}0.0758^{*} \\
(0.045)\end{array}$ & $\begin{array}{l}0.0919 \\
(0.058)\end{array}$ & $\begin{array}{c}0.1690^{* *} \\
(0.065)\end{array}$ & & $\begin{array}{c}0.1941^{* *} \\
(0.085)\end{array}$ & $\begin{array}{l}0.1690^{*} \\
(0.092)\end{array}$ & $\begin{array}{l}0.1286 \\
(0.089)\end{array}$ & $\begin{array}{l}0.1865 \\
(0.118)\end{array}$ & & $\begin{array}{c}0.0926^{* *} \\
(0.043)\end{array}$ & $\begin{array}{l}0.0747^{*} \\
(0.043)\end{array}$ & $\begin{array}{l}0.1018^{*} \\
(0.054)\end{array}$ & $\begin{array}{c}0.1897^{* * * *} \\
(0.059)\end{array}$ \\
\hline World Real Export Growth & & $\begin{array}{l}-0.0190 \\
(0.062)\end{array}$ & $\begin{array}{l}-0.0156 \\
(0.064)\end{array}$ & $\begin{array}{l}-0.0245 \\
(0.075)\end{array}$ & $\begin{array}{l}-0.1270 \\
(0.088)\end{array}$ & & $\begin{array}{l}-0.0913 \\
(0.095)\end{array}$ & $\begin{array}{c}-0.0877 \\
(0.100)\end{array}$ & $\begin{array}{l}-0.0761 \\
(0.118)\end{array}$ & $\begin{array}{l}-0.2268 \\
(0.164)\end{array}$ & & $\begin{array}{l}-0.0437 \\
(0.059)\end{array}$ & $\begin{array}{c}-0.0386 \\
(0.060)\end{array}$ & $\begin{array}{l}-0.0602 \\
(0.071)\end{array}$ & $\begin{array}{l}-0.1554 \\
(0.096)\end{array}$ \\
\hline IMF Emerging Mkt Dummy & & $\begin{array}{c}0.0178^{* *} \\
(0.008)\end{array}$ & $\begin{array}{l}0.0163^{*} \\
(0.008)\end{array}$ & $\begin{array}{l}0.0029 \\
(0.016)\end{array}$ & $\begin{array}{l}0.0048 \\
(0.013)\end{array}$ & & $\begin{array}{c}0.0266 * * \\
(0.012)\end{array}$ & $\begin{array}{l}0.0238^{*} \\
(0.012)\end{array}$ & $\begin{array}{l}0.0083 \\
(0.027)\end{array}$ & $\begin{array}{c}-0.0026 \\
(0.020)\end{array}$ & & $\begin{array}{l}0.0137^{*} \\
(0.008)\end{array}$ & $\begin{array}{l}0.0123 \\
(0.008)\end{array}$ & $\begin{array}{l}0.0023 \\
(0.015)\end{array}$ & $\begin{array}{l}-0.0038 \\
(0.012)\end{array}$ \\
\hline Exchange Rate Regime & & $\begin{array}{l}-0.0019 \\
(0.003)\end{array}$ & & & & & $\begin{array}{l}0.0006 \\
(0.005)\end{array}$ & & & & & $\begin{array}{c}-0.0012 \\
(0.003)\end{array}$ & & & \\
\hline Debt/GDP & & & $\begin{array}{c}-0.0003^{* *} \\
(0.000)\end{array}$ & & & & & $\begin{array}{c}-0.0002 \\
(0.000)\end{array}$ & & & & & $\begin{array}{c}-0.0003^{* *} \\
(0.000)\end{array}$ & & \\
\hline Original Sin & & & & $\begin{array}{c}-0.0975^{*} \\
(0.056)\end{array}$ & & & & & $\begin{array}{r}-0.0816 \\
(0.092)\end{array}$ & & & & & $\begin{array}{l}-0.0776 \\
(0.053)\end{array}$ & \\
\hline Financial Dollarization & & & & & $\begin{array}{c}0.0026^{* * * *} \\
(0.001)\end{array}$ & & & & & $\begin{array}{c}0.0030 * * * \\
(0.001)\end{array}$ & & & & & $\begin{array}{c}0.0024^{* * *} \\
(0.001)\end{array}$ \\
\hline Observations & 311 & 182 & 181 & 120 & 92 & 192 & 113 & 111 & 93 & 60 & 313 & 183 & 182 & 121 & 92 \\
\hline Nr. of countries & 93 & 87 & 87 & 68 & 50 & 58 & 58 & 58 & 54 & 34 & 93 & 87 & 87 & 68 & 50 \\
\hline R-squared & 0.039 & 0.087 & 0.109 & 0.101 & 0.235 & 0.067 & 0.167 & 0.175 & 0.128 & 0.281 & 0.059 & 0.103 & 0.128 & 0.126 & 0.256 \\
\hline
\end{tabular}

Openness1 is measured as the ratio of exports plus imports to GDP, Openness2 as the share imports in total consumption, while Openness3 is the ratio of in
in Columns (1), (6) and (11)) and a constant term are included but not reported. Robust standard errors in parentheses. $* * * \mathrm{p}<0.01,{ }^{*} \mathrm{p}<0.05, * \mathrm{p}<0.1$ 


\subsection{Openness, current-account reversals and exchange rates during abrupt exchange rate depreciations}

We follow the same empirical strategy as in the previous section to study the link between openness and the balance of payments during events of abrupt exchange rate depreciations. Since these events are generally similar or accompanied by sudden stops we expect similar associations between our main variables of interest. Table 3 presents the results of the regressions explaining current-account changes in events of abrupt depreciations in exchange rates. Comparing to the results in Table 1, we notice important similarities. Current-account improvements tend to be larger when real exchange rate depreciations are larger and when the economy is more open to trade. Again, the coefficients of the three measures of openness are positive and highly significant. For abrupt RER depreciation episodes, these effects are significant and robust to the inclusion of similar control variables as in Section 4.1.

Differently from the episodes of sudden stops, however, we now find not only a significant impact of the changes in the terms of trade, but also of the emerging market dummy and the proxies for external debt. We find that countries with higher Debt/GDP or higher debt denominated in foreign currency (Original Sin) are associated with lower current account reversals during episodes of real exchange rate depreciation. However, contrary to our expectations, we find that countries with more foreign currency denominated debt also enjoy larger reversals in current account. This means that the increased interest payments due to the depreciation of the currency is offset by the reversal in trade balance. Finally, we also check the robustness of these results when considering abrupt changes in real effective exchange rates. Results, presented in Appendix Table A4, are qualitatively the same.

Table 4 presents the results obtained under the same specifications as in Table 3, but looking this time at the impact on trade balance variation. Here, again, exchange rate depreciations and openness have a positive and significant impact on trade balance, and this impact is robust to the inclusion of a number of control variables.

We view the evidence presented in this section as complementary to the previous one in highlighting the important role that trade openness might play during extreme events such as sudden stops or abrupt exchange rate depreciations. 
Table 4: Trade balance and openness during RER depreciation episodes

\begin{tabular}{|c|c|c|c|c|c|c|c|c|c|c|c|c|c|c|c|}
\hline & (1) & (2) & (3) & (4) & 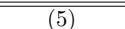 & 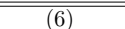 & 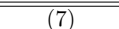 & 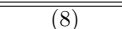 & 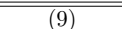 & 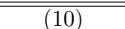 & 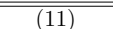 & 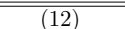 & 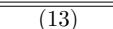 & 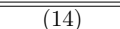 & $\overline{(15)}$ \\
\hline Openness1 1 & $\begin{array}{l}0.0248^{*} \\
(0.013)\end{array}$ & $\begin{array}{l}0.0355^{*} \\
(0.019)\end{array}$ & $\begin{array}{l}0.0346 \\
(0.022)\end{array}$ & $\begin{array}{c}0.0265^{* *} \\
(0.011)\end{array}$ & $\begin{array}{c}0.0473^{* *} \\
(0.018)\end{array}$ & & & & & & & & & & \\
\hline Openness2 & & & & & & $\begin{array}{c}0.0559^{* * *} \\
(0.019)\end{array}$ & $\begin{array}{c}0.0931^{* * *} \\
(0.029)\end{array}$ & $\begin{array}{c}0.0905^{* * *} \\
(0.028)\end{array}$ & $\begin{array}{c}0.0690 * * * \\
(0.023)\end{array}$ & $\begin{array}{c}0.1530 * * * \\
(0.049)\end{array}$ & & & & & \\
\hline Openness3 & & & & & & & & & & & $\begin{array}{c}0.0796^{* *} \\
(0.035)\end{array}$ & $\begin{array}{c}0.1024^{* *} \\
(0.052)\end{array}$ & $\begin{array}{l}0.1039^{*} \\
(0.057)\end{array}$ & $\begin{array}{c}0.0825^{* * *} \\
(0.026)\end{array}$ & $\begin{array}{c}0.1197^{* * *} \\
(0.043)\end{array}$ \\
\hline$\Delta$ RER & $\begin{array}{c}0.0556^{* *} \\
(0.025)\end{array}$ & $\begin{array}{l}0.0467 \\
(0.036)\end{array}$ & $\begin{array}{l}0.0294 \\
(0.029)\end{array}$ & $\begin{array}{c}0.0645^{* * *} \\
(0.024)\end{array}$ & $\begin{array}{c}0.0668^{* * *} \\
(0.018)\end{array}$ & $\begin{array}{l}0.0453 \\
(0.035)\end{array}$ & $\begin{array}{l}0.0459 \\
(0.042)\end{array}$ & $\begin{array}{l}0.0490 \\
(0.045)\end{array}$ & $\begin{array}{c}0.1090^{* * *} \\
(0.025)\end{array}$ & $\begin{array}{c}0.1050^{* * *} \\
(0.036)\end{array}$ & $\begin{array}{c}0.0638^{* *} \\
(0.025)\end{array}$ & $\begin{array}{l}0.0515 \\
(0.036)\end{array}$ & $\begin{array}{l}0.0389 \\
(0.031)\end{array}$ & $\begin{array}{c}0.0706 * * \\
(0.027)\end{array}$ & $\begin{array}{c}0.0757^{* * * *} \\
(0.020)\end{array}$ \\
\hline Control Variables: & & & & & & & & & & & & $01443 * * *$ & & $01971 * * *$ & $02033 * * *$ \\
\hline World Beal Export Growth & & $\begin{array}{c}0.1417^{* * * *} \\
(0.039) \\
0.0312\end{array}$ & $\begin{array}{c}0.1283^{* * *} \\
(0.036) \\
0.0246\end{array}$ & $\begin{array}{c}0.1721^{* *} \\
(0.070) \\
0.0244\end{array}$ & $\begin{array}{c}0.2074^{* * *} \\
(0.059) \\
-0.0849\end{array}$ & & $\begin{array}{c}0.2295^{* *} \\
(0.104) \\
-0.0311\end{array}$ & $\begin{array}{c}0.2418^{* *} \\
(0.120) \\
-0.0473\end{array}$ & $\begin{array}{c}0.2168^{*} \\
(0.110) \\
-0.0278\end{array}$ & $\begin{array}{l}0.3417^{*} \\
(0.175) \\
-0.1632\end{array}$ & & $\begin{array}{c}0.1443^{* * *} \\
(0.039) \\
0.0274\end{array}$ & $\begin{array}{c}0.1325^{* \text { *** }} \\
(0.036) \\
0.0239\end{array}$ & $\begin{array}{c}0.19 .11 \cdots \\
(0.071) \\
0.0210\end{array}$ & $\begin{array}{c}0.2333 \cdots \\
(0.060) \\
-0.0924\end{array}$ \\
\hline World Real Export Growth & & $\begin{array}{l}0.0312 \\
(0.042)\end{array}$ & $\begin{array}{l}0.0246 \\
(0.041)\end{array}$ & $\begin{array}{l}0.0244 \\
(0.053)\end{array}$ & $\begin{array}{l}-0.0049 \\
(0.051)\end{array}$ & & $\begin{array}{c}-0.0311 \\
(0.063)\end{array}$ & $\begin{array}{l}-0.0407 \\
(0.067)\end{array}$ & $\begin{array}{l}-0.0210 \\
(0.072)\end{array}$ & $\begin{array}{l}-0.1002 \\
(0.112)\end{array}$ & & $(0.043)$ & $\begin{array}{l}0.0239 \\
(0.042)\end{array}$ & $(0.054)$ & $\begin{array}{l}-0.0524 \\
(0.057)\end{array}$ \\
\hline IMF Emerging Mkt Dummy & & $\begin{array}{l}0.0163^{*} \\
(0.009)\end{array}$ & $\begin{array}{l}0.0133 \\
(0.009)\end{array}$ & $\begin{array}{l}0.0009 \\
(0.011)\end{array}$ & $\begin{array}{l}-0.0103 \\
(0.013)\end{array}$ & & $\begin{array}{l}0.0175^{*} \\
(0.010)\end{array}$ & $\begin{array}{c}0.0199^{* *} \\
(0.009)\end{array}$ & $\begin{array}{l}-0.0049 \\
(0.021)\end{array}$ & $\begin{array}{c}-0.0093 \\
(0.019)\end{array}$ & & $\begin{array}{l}0.0103 \\
(0.008)\end{array}$ & $\begin{array}{l}0.0081 \\
(0.008)\end{array}$ & $\begin{array}{l}0.0011 \\
(0.010)\end{array}$ & $\begin{array}{l}-0.0123 \\
(0.011)\end{array}$ \\
\hline Exchange Rate Regime & & $\begin{array}{c}-0.0078^{*} \\
(0.005)\end{array}$ & & & & & $\begin{array}{l}0.0039 \\
(0.004)\end{array}$ & & & & & $\begin{array}{l}-0.0055 \\
(0.004)\end{array}$ & & & \\
\hline Debt/GDP & & & $\begin{array}{l}-0.0002 \\
(0.000)\end{array}$ & & & & & $\begin{array}{l}0.0001 \\
(0.000)\end{array}$ & & & & & $\begin{array}{l}-0.0002 \\
(0.000)\end{array}$ & & \\
\hline Original Sin & & & & $\begin{array}{c}-0.0938^{* *} \\
(0.039)\end{array}$ & & & & & $\begin{array}{l}-0.1023 \\
(0.077)\end{array}$ & & & & & $\begin{array}{c}-0.0764^{* *} \\
(0.038)\end{array}$ & \\
\hline Financial Dollarization & & & & & $\begin{array}{c}0.0034^{* * *} \\
(0.001)\end{array}$ & & & & & $\begin{array}{c}0.0036^{* * *} \\
(0.001)\end{array}$ & & & & & $\begin{array}{c}0.0033^{* * *} \\
(0.001)\end{array}$ \\
\hline Observations & 575 & 282 & 280 & 139 & 133 & 210 & 117 & 115 & 94 & 63 & 575 & 282 & 280 & 139 & 133 \\
\hline Nr. of countries & 133 & 118 & 117 & 75 & 67 & 60 & 60 & 60 & 55 & 35 & 133 & 118 & 117 & 75 & 67 \\
\hline R-squared & 0.029 & 0.138 & 0.109 & 0.140 & 0.231 & 0.070 & 0.161 & 0.158 & 0.194 & 0.327 & 0.072 & 0.226 & 0.207 & 0.181 & 0.283 \\
\hline
\end{tabular}

Openness1 is measured as the ratio of exports plus imports to GDP, Openness2 as the share imports in total consumption, while Openness 3 is the ratio of in
in Columns (1), (6) and (11)) and a constant term are included but not reported. Robust standard errors in parentheses, $* * * \mathrm{p}<0.01, * * \mathrm{p}^{*}<0.05,{ }^{*} \mathrm{p}<0.1$. 


\subsection{Robustness checks}

Apart from the use of three alternative proxies for trade openness and the use of both real exchange rates and real effective exchange rates, we perform a series of other robustness checks, in particular with regards to the identification methodology of sudden and abrupt exchange rate depreciations, as well as the specification of the sample.

First, we redefine sudden stops and exchange rate depreciations by looking at both the five years and historical averages as a threshold for identifying the events. This latter method is also employed by Calvo et al. (2004). This alternative identification strategy reduces the number of shocks identified, however it does not significantly impact our main results. We present the results for these robustness checks in Appendix Table A5 for the five year average and in Appendix Table A6 for the historical average, respectively. ${ }^{12}$

Next, we exclude from our sample events that also correspond to banking and currency crisis. We do this by cross checking whether any of the shocks identified using our methodology happen in years in which Laeven and Valencia (2013) identified a banking or a currency crises.

Finally, we re-run our estimations excluding all the sudden stops in which an abrupt depreciation occurred in the quarter before the episode window of such event. We also excluded all depreciations anticipated by a sudden stop. Again, all of these checks do not impact our results quantitatively. The results of the robustness checks have not been included here, but are available upon request.

\section{$5 \quad$ Concluding remarks}

We investigate whether openness to trade facilitates current account and trade balance improvements. To this end, we identify events of sudden stops in capital flows and of abrupt exchange rate depreciations and we check whether openness helps explain current account and trade balance improvements.

We present a simple theoretical framework that highlights the mechanism through which openness should affect the relation between current-account changes and real exchange rate depreciation. It should be noted that, according to this simple model, the size of the exchange rate depreciation does not have any impact on welfare. Welfare changes depend on the size of the income shocks that cause the sudden stop, but not on how the economy adapts to it. More specifically, whether the economy adjusts through major relative price changes or through income effects.

In line with the predictions of our theoretical model, we find that the degree of openness has a positive effect on changes in current account and on

\footnotetext{
${ }^{12} \mathrm{We}$ also check the robustness of our results with respect to the variations in trade balance. Results are qualitatively the same and can be obtained from the authors.
} 
trade balance. Our results indicate that more open economies can rebalance their current account and trade balance with smaller domestic currency depreciations after an external shock. Hence, more open economies would be better able to overcome external shocks that entails the need of currentaccount reversals.

\section{References}

Abbas, S., N. Belhocine, A. A. ElGanainy, and M. Horton (2010). A historical public debt database. IMF Working Papers, 1-26.

Bianchi, J. (2011). Overborrowing and systemic externalities in the business cycle. American Economic Review 101(7), 3400-3426.

Broner, F., T. Didier, A. Erce, and S. L. Schmukler (2013). Gross capital flows: Dynamics and crises. Journal of Monetary Economics 60(1), 113133.

Bussière, M., G. Callegari, F. Ghironi, G. Sestieri, and N. Yamano (2013). Estimating Trade Elasticities: Demand Composition and the Trade Collapse of 2008-2009. American Economic Journal: Macroeconomics 5(3), $118-51$.

Calderón, C. and M. Kubota (2013). Sudden stops: Are global and local investors alike? Journal of International Economics 89(1), 122-142.

Calvo, G. A., A. Izquierdo, and L.-F. Mejia (2004). On the empirics of sudden stops: The relevance of balance-sheet effects. NBER Working Papers 10520, National Bureau of Economic Research, Inc.

Cavallo, E. A. and J. A. Frankel (2008). Does openness to trade make countries more vulnerable to sudden stops, or less? using gravity to establish causality. Journal of International Money and Finance 27(8), 1430-1452.

Corsetti, G., P. Martin, and P. Pesenti (2013). Varieties and the transfer problem. Journal of International Economics 89(1), 1-12.

Edwards, S. (2004). Financial openness, sudden stops, and current-account reversals. The American Economic Review 94(2), 59-64.

Eichengreen, B., A. K. Rose, C. Wyplosz, B. Dumas, and A. Weber (1995). Exchange market mayhem: The antecedents and aftermath of speculative attacks. Economic Policy 10(21), pp. 249-312.

Forbes, K. J. and F. E. Warnock (2012). Capital flow waves: Surges, stops, flight, and retrenchment. Journal of International Economics 88(2), 235251. \{NBER\} Global. 
Glick, R. and M. Hutchison (2011). Currency crises. Working Paper Series 2011-22, Federal Reserve Bank of San Francisco.

Gourinchas, P.-O. and M. Obstfeld (2012). Stories of the twentieth century for the twenty-first. American Economic Journal: Macroeconomics 4(1), 226-65.

Guidotti, P. E., F. Sturzenegger, A. Villar, J. d. Gregorio, and I. Goldfajn (2004). On the consequences of sudden stops. Economia 4 (2), 171-214.

Hausmann, R. and U. Panizza (2003). On the determinants of Original Sin: an empirical investigation. Journal of International Money and Finance 22(7), 957-990.

Ilzetzki, E., C. Reinhart, and K. Rogoff (2008). Exchange rate arrangements entering the 21st century: Which anchor will hold? mimeo.

Keynes, J. M. (1929). The German transfer problem. The Economic Journal $39(153), 1-7$.

Korinek, A. and E. G. Mendoza (2013). From sudden stops to fisherian deflation: Quantitative theory and policy implications. Working Paper 19362, National Bureau of Economic Research.

Laeven, L. and F. Valencia (2013). Systemic banking crises database. IMF Economic Review 61(2), 225-270.

Levy Yeyati, E. (2006). Financial dollarization: evaluating the consequences. Economic Policy 21(45), 61-118.

Melitz, M. J. (2003). The Impact of Trade on Intra-Industry Reallocations and Aggregate Industry Productivity. Econometrica 71(6), 1695-1725.

Mendoza, E. G. (2005). Real exchange rate volatility and the price of nontradable goods in economies prone to sudden stops. Economia.

Mendoza, E. G. (2010). Sudden stops, financial crises, and leverage. American Economic Review $100(5), 1941-66$.

Milesi-Ferretti, G.-M. and A. Razin (2000). Current account reversals and currency crises, empirical regularities. In Currency Crises, NBER Chapters, pp. 285-326. National Bureau of Economic Research, Inc.

Obstfeld, M. and K. Rogoff (2007). The unsustainable u.s. current account position revisited. In G7 Current Account Imbalances: Sustainability and Adjustment, NBER Chapters, pp. 339-376. National Bureau of Economic Research, Inc. 
Obstfeld, M. and K. S. Rogoff (2005). Global current account imbalances and exchange rate adjustments. Brookings Papers on Economic Activity 36(1), 67-146.

Ohlin, B. (1929). The reparation problem: a discussion. Economic Journal 39(154), 172-182.

Reinhart, C. M. and G. L. Kaminsky (1999). The Twin Crises: The Causes of Banking and Balance-of-Payments Problems. American Economic Review $89(3), 473-500$.

Reinhart, C. M. and K. S. Rogoff (2004). The modern history of exchange rate arrangements: A reinterpretation. The Quarterly Journal of Economics 119(1), 1-48.

Rey, H. and P. Martin (2006). Globalization and emerging markets: With or without crash? American Economic Review 96(5), 1631-1651.

Rothenberg, A. D. and F. E. Warnock (2011). Sudden flight and true sudden stops. Review of International Economics 19(3), 509-524.

Silva, J. M. C. S. and S. Tenreyro (2006). The Log of Gravity. The Review of Economics and Statistics 88(4), 641-658.

Tovar, C. E. (2005). International government debt denominated in local currency: recent developments in latin america. BIS Quarterly Review, December.

Yanikkaya, H. (2003). Trade openness and economic growth: a cross-country empirical investigation. Journal of Development Economics 72(1), 57 89. 
Appendix Tables 
Table A1: Analyzed countries and data availability

\begin{tabular}{|c|c|c|c|c|c|c|c|}
\hline Country & $\begin{array}{c}\text { Capital } \\
\text { Flows }\end{array}$ & $\triangle$ RER & $\Delta$ REER & Country & $\begin{array}{c}\text { Capital } \\
\text { Flows }\end{array}$ & $\triangle$ RER & $\triangle$ REER \\
\hline Afghanistan & - & $2005-2011$ & - & Estonia & 1993-2011 & 1993-2012 & - \\
\hline Albania & $1996-2011$ & $1993-2011$ & - & Ethiopia & 1978-2009 & $1967-2011$ & - \\
\hline Algeria & - & $1975-2011$ & $1981-2011$ & Euro Area & 2000-2011 & - & 1981-2011 \\
\hline Angola & - & 1993-2011 & - & Fiji & 2001-2010 & $1970-2011$ & 1981-2011 \\
\hline Anguilla & - & 1999-2011 & - & Finland & 1976-2011 & 1966-2012 & 1968-2011 \\
\hline Antigua and Barbuda & - & - & $1977-2011$ & France & 1976-2011 & 1966-2012 & 1981-2011 \\
\hline Argentina & 1977-2011 & 1966-2011 & - & Gabon & - & 1966-2011 & 1981-2011 \\
\hline Armenia & 1994-2011 & 1994-2011 & 1995-2011 & Gambia, The & 2008-2010 & 1966-2011 & 1981-2011 \\
\hline Aruba & $1987-2010$ & $1987-2011$ & - & Georgia & 1998-2011 & 1996-2012 & 1994-2011 \\
\hline Australia & $1966-2010$ & $1966-2011$ & $1981-2011$ & Germany & 1972-2011 & 1966-2012 & 1976-2011 \\
\hline Austria & 1971-2011 & 1966-2012 & 1976-2011 & Ghana & - & 1966-2011 & 1981-2011 \\
\hline Azerbaijan & 2000-2011 & - & - & Greece & 1977-2011 & 1966-2012 & 1981-2011 \\
\hline Bahamas, The & $1977-2011$ & $1967-2011$ & 1981-2011 & Grenada & - & $1977-2011$ & 1977-2011 \\
\hline Bahrain, Kingdom of & - & $1967-2011$ & 1981-2011 & Guatemala & 1978-2011 & 1966-2011 & - \\
\hline Bangladesh & $1977-2011$ & 1994-2011 & - & Guinea & - & 2005-2011 & - \\
\hline Barbados & - & $1966-2011$ & - & Guinea-Bissau & - & $1987-2011$ & - \\
\hline Belarus & 2003-2011 & - & - & Guyana & - & $1995-2011$ & 1981-2011 \\
\hline Belgium & 2003-2011 & 1966-2012 & 1976-2011 & Haiti & - & 1966-2011 & - \\
\hline Belize & 2002-2011 & $1984-2011$ & $1981-2011$ & Honduras & 2005-2011 & 1966-2012 & - \\
\hline Benin & - & 1993-2011 & - & Hungary & $1990-2011$ & $1977-2012$ & 1981-2011 \\
\hline Bhutan & - & $1980-2010$ & - & Iceland & $1977-2011$ & 1966-2012 & 1976-2011 \\
\hline Bolivia & 1978-2010 & 1966-2011 & 1981-2011 & India & 1976-2010 & 1966-2011 & - \\
\hline Bosnia and Herzegovina & 2002-2011 & 2007-2011 & - & Indonesia & 1982-2011 & 1969-2012 & - \\
\hline Botswana & - & $1975-2011$ & - & Iran, Islamic Republic of & - & $1966-2011$ & 1976-2011 \\
\hline Brazil & 1976-2011 & 1981-2012 & $1981-2011$ & Iraq & - & 1966-2011 & - \\
\hline Brunei Darussalam & 2003-2009 & $1985-2011$ & - & Ireland & 1982-2011 & 1966-2012 & 1976-2011 \\
\hline Bulgaria & 1993-2011 & $1992-2012$ & 1993-2011 & Israel & 1973-2011 & 1966-2012 & 1976-2011 \\
\hline Burkina Faso & - & $1966-2011$ & - & Italy & $1971-2011$ & $1966-2012$ & $1981-2011$ \\
\hline Burundi & - & 1966-2011 & 1976-2011 & Jamaica & - & 1966-2012 & - \\
\hline Cambodia & $1995-2010$ & $1995-2011$ & - & Japan & 1978-2011 & 1966-2011 & 1981-2011 \\
\hline Cameroon & 1980-1987 & 1969-2011 & 1981-2011 & Jordan & 1978-2011 & $1977-2012$ & - \\
\hline Canada & 1966-2011 & 1966-2011 & 1976-2011 & Kazakhstan & 1996-2011 & 1994-2012 & - \\
\hline Cape Verde & 1999-2011 & $1985-2012$ & - & Kenya & - & 1966-2012 & - \\
\hline Central African Rep. & - & $1982-2010$ & $1981-2011$ & Korea, Republic of & $1977-2011$ & 1971-2012 & - \\
\hline Chad & - & $1984-2010$ & - & Kosovo & 2010-2011 & - & - \\
\hline Chile & 1992-2011 & - & $1981-2011$ & Kuwait & - & 1974-2011 & - \\
\hline China, P.R.: Hong Kong & $2000-2011$ & $1981-2011$ & - & Kyrgyz Republic & 1996-2011 & 1996-2011 & - \\
\hline China, P.R.: Macao & - & $1989-2011$ & - & Lao, P.D.R. & $1995-2010$ & $1989-2010$ & - \\
\hline China, P.R.: Mainland & 2011-2011 & - & 1981-2011 & Latvia & 1994-2011 & 1993-2012 & - \\
\hline Colombia & $1997-2011$ & 1966-2012 & $1981-2011$ & Lebanon & 2003-2010 & - & - \\
\hline Congo, Dem. Rep. of & - & 1966-2009 & $1981-2010$ & Lesotho & $1986-2007$ & 1974-2011 & 1976-2011 \\
\hline Congo, Republic of & - & $1991-2010$ & - & Libya & - & 1966-2011 & - \\
\hline Costa Rica & 2000-2011 & 1966-2011 & $1981-2011$ & Lithuania & 1994-2011 & 1993-2012 & - \\
\hline Cote d'Ivoire & - & $1966-2011$ & $1981-2011$ & Luxembour & 1996-2011 & 1966-2012 & 1976-2011 \\
\hline Croatia & 1994-2011 & 1993-2012 & 1993-2011 & Macedonia, FYR & $1997-2010$ & 1994-2012 & 1993-2011 \\
\hline Cyprus & 2002-2011 & 1966-2012 & $1981-2011$ & Madagascar & 2004-2005 & 1966-2011 & - \\
\hline Czech Republic & 1994-2011 & 1994-2012 & 1991-2011 & Malawi & - & 1981-2011 & 1981-2011 \\
\hline Czechoslovakia & $1990-1992$ & - & - & Malaysia & $2000-2010$ & $1966-2011$ & $1976-2011$ \\
\hline Denmark & 1976-2011 & 1966-2012 & 1976-2011 & Maldives & - & 2005-2011 & - \\
\hline Djibouti & - & $1982-2011$ & - & Mali & - & $1988-2011$ & - \\
\hline Dominica & - & $1966-2011$ & 1976-2011 & Malta & 1996-2011 & 1966-2011 & 1976-2011 \\
\hline Dominican Republic & - & 1966-2012 & 1981-2011 & Maurita & - & $1986-2011$ & - \\
\hline Ecuador & $1994-2011$ & - & $1981-2011$ & Mauritius & 2001-2010 & $1966-2012$ & - \\
\hline Egypt & - & 1966-2011 & - & Mexico & $1980-2011$ & 1966-2012 & 1981-2011 \\
\hline El Salvador & 2000-2011 & 1966-2012 & - & Moldova & 1995-2011 & $1995-2011$ & 1995-2011 \\
\hline Equatorial Guinea & - & $1986-2008$ & 1986-2011 & Mongolia & 2005-2010 & $1992-2011$ & - \\
\hline Eritrea & 1999-2000 & - & - & Montenegro, Republic of & - & 2006-2011 & - \\
\hline
\end{tabular}




\begin{tabular}{|c|c|c|c|c|c|c|c|}
\hline Country & $\begin{array}{l}\text { Capital } \\
\text { Flows }\end{array}$ & $\Delta$ RER & $\Delta$ REER & Country & $\begin{array}{l}\text { Capital } \\
\text { Flows }\end{array}$ & $\Delta$ RER & $\Delta$ REER \\
\hline Morocco & 2004-2010 & $1966-2011$ & 1981-2011 & Slovak Republic & $1994-2010$ & 1994-2012 & $1991-2011$ \\
\hline Mozambique & $2000-2010$ & 1993-2011 & - & Slovenia & $1993-2011$ & 1993-2012 & - \\
\hline Myanmar & $1977-2011$ & 1971-2011 & - & Solomon Islands & $2007-2010$ & 1971-2011 & $1979-2011$ \\
\hline Namibia & $2000-2010$ & 2003-2012 & - & South Africa & $1966-2011$ & 1966-2012 & $1976-2011$ \\
\hline Nepal & $1978-2010$ & $1966-2011$ & - & Spain & $1976-2011$ & $1966-2012$ & 1981-2011 \\
\hline Netherlands & 1968-2011 & 1966-2012 & 1976-2011 & Sri Lanka & $1978-2010$ & 1966-2011 & - \\
\hline Netherlands Antilles & $1999-2010$ & $1969-2010$ & $1976-2010$ & St. Kitts and Nevis & - & $1980-2011$ & $1976-2011$ \\
\hline New Zealand & 1981-2011 & $1966-2011$ & 1976-2011 & St. Lucia & - & $1966-2011$ & $1976-2011$ \\
\hline Nicaragua & 1994-2011 & $2000-2012$ & 1981-2011 & St. Vinc. and the Gren. & - & 1976-2011 & $1976-2011$ \\
\hline Niger & - & 1969-2011 & - & Sudan & $1978-2010$ & $1966-2011$ & - \\
\hline Nigeria & 1991-1994 & $1966-2011$ & 1981-2011 & Suriname & $1978-2010$ & $1966-2011$ & - \\
\hline Norway & $1976-2011$ & 1966-2012 & $1976-2011$ & Swaziland & - & $1966-2011$ & - \\
\hline Oman & - & $2002-2011$ & - & Sweden & $1976-2011$ & 1966-2012 & $1976-2011$ \\
\hline Pakistan & 1977-2011 & 1966-2011 & 1981-2011 & Switzerland & $2000-2011$ & 1966-2012 & $1976-2011$ \\
\hline Panama & 1999-2011 & 1966-2011 & - & Tajikistan & $2003-2010$ & - & - \\
\hline Papua New Guinea & $1977-2001$ & $1972-2011$ & $1981-2011$ & Tanzania & - & $1970-2012$ & - \\
\hline Paraguay & 2002-2011 & 1966-2011 & 1981-2011 & Thailand & $1977-2011$ & 1966-2012 & - \\
\hline Peru & 1978-2011 & 1966-2012 & - & Togo & - & 1971-2011 & $1981-2011$ \\
\hline Philippines & 1978-2011 & 1966-2012 & 1976-2011 & Tonga & $1978-2010$ & 1977-2011 & - \\
\hline Poland & $1986-2011$ & 1981-2012 & 1981-2011 & Trinidad and Tobago & - & $1966-2011$ & $1976-2011$ \\
\hline Portugal & $1976-2011$ & 1966-2012 & $1976-2011$ & Tunisia & - & $1988-2011$ & $1976-2011$ \\
\hline Qatar & - & 2004-2012 & - & Turkey & $1985-2011$ & $1970-2012$ & - \\
\hline Romania & $1992-2011$ & 1991-2012 & 1981-2011 & Uganda & $1981-2010$ & $1982-2012$ & $1981-2011$ \\
\hline Russian Federation & $1995-2011$ & 1993-2011 & 1995-2011 & Ukraine & $1995-2011$ & 1993-2012 & $1993-2011$ \\
\hline Rwanda & - & $1966-2012$ & - & United Kingdom & 1971-2011 & $1966-2012$ & $1976-2011$ \\
\hline Samoa & 2004-2011 & 1966-2011 & 1976-2011 & United States & $1974-2011$ & $1966-2012$ & 1981-2011 \\
\hline San Marino & - & 2004-2010 & - & Uruguay & $2001-2010$ & 1966-2011 & 1981-2011 \\
\hline Saudi Arabia & 2007-2011 & 1972-2011 & 1981-2011 & Vanuatu & $1985-2008$ & 1977-2011 & - \\
\hline Senegal & - & $1969-2011$ & - & Venezuela, Rep. Boliv. & $1995-2011$ & 1966-2011 & $1981-2011$ \\
\hline Serbia, Republic of & 2009-2011 & $1998-2011$ & - & Vietnam & - & 1996-2011 & - \\
\hline Seychelles & $1980-2011$ & 1970-2011 & - & Yemen, Republic of & $2001-2010$ & 1998-2011 & - \\
\hline Sierra Leone & - & - & 1981-2011 & Zambia & - & 1986-2011 & $1981-2011$ \\
\hline Singapore & 1996-2010 & 1966-2011 & 1976-2011 & Zimbabwe & 1982-1994 & - & - \\
\hline
\end{tabular}


Table A2: Current account and openness during sudden stops: REER estimations

\begin{tabular}{|c|c|c|c|c|c|c|c|c|c|c|c|c|c|c|c|}
\hline & & & & & & & & & & & & & & & \\
\hline & (1) & $(2)$ & (3) & (4) & (5) & 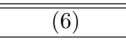 & $(7)$ & (8) & $(9)$ & $\begin{array}{lll}(10) \\
\end{array}$ & (11) & (12) & (13) & (14) & (15) \\
\hline Openness1 & $\begin{array}{c}0.0194^{* * *} \\
(0.006)\end{array}$ & $\begin{array}{c}0.0228 * * * \\
(0.008)\end{array}$ & $\begin{array}{c}0.0231^{* * *} \\
(0.008)\end{array}$ & $\begin{array}{c}0.0294^{* *} \\
(0.012)\end{array}$ & $\begin{array}{l}0.0389 \\
(0.024)\end{array}$ & & & & & & & & & & \\
\hline Openness2 & & & & & & $\begin{array}{c}0.0310^{* * *} \\
(0.010)\end{array}$ & $\begin{array}{c}0.0420^{* *} \\
(0.017)\end{array}$ & $\begin{array}{c}0.0316^{*} \\
(0.016)\end{array}$ & $\begin{array}{c}0.0336^{* *} \\
(0.015)\end{array}$ & $\begin{array}{c}0.0558^{* *} \\
(0.022)\end{array}$ & & & & & \\
\hline Openness3 & & & & & & & & & & & $\begin{array}{c}0.0391 * * * \\
(0.011)\end{array}$ & $\begin{array}{c}0.0435^{* * *} \\
(0.016)\end{array}$ & $\begin{array}{c}0.0442^{* * *} \\
(0.015)\end{array}$ & $\begin{array}{l}0.0441 \\
(0.029)\end{array}$ & $\begin{array}{l}0.0720 \\
(0.048)\end{array}$ \\
\hline$\triangle$ REER & $\begin{array}{l}0.0634 \\
(0.043)\end{array}$ & $\begin{array}{c}0.1049^{* *} \\
(0.048)\end{array}$ & $\begin{array}{l}0.1005^{*} \\
(0.050)\end{array}$ & $\begin{array}{l}0.0703 \\
(0.076)\end{array}$ & $\begin{array}{l}0.1083 \\
(0.083)\end{array}$ & $\begin{array}{l}0.0798 \\
(0.053)\end{array}$ & $\begin{array}{c}0.1308 * * * \\
(0.045)\end{array}$ & $\begin{array}{c}0.1344^{* *} \\
(0.053)\end{array}$ & $\begin{array}{l}0.1041 \\
(0.069)\end{array}$ & $\begin{array}{c}0.1498^{* *} \\
(0.058)\end{array}$ & $\begin{array}{l}0.0625 \\
(0.041)\end{array}$ & $\begin{array}{c}0.0922^{*} \\
(0.048)\end{array}$ & $\begin{array}{l}0.0848 \\
(0.051)\end{array}$ & $\begin{array}{l}0.0398 \\
(0.078)\end{array}$ & $\begin{array}{l}0.1026 \\
(0.083)\end{array}$ \\
\hline Control Variables: & & & & & & & & & & & & & & & \\
\hline$\Delta$ Terms of Trade & & $\begin{array}{l}0.0700 \\
(0.044)\end{array}$ & $\begin{array}{l}0.0618 \\
(0.049)\end{array}$ & 0.0770 & $\begin{array}{l}0.0589 \\
(0.050)\end{array}$ & & $\begin{array}{l}0.0906 \\
(0.058)\end{array}$ & 0.0917 & $\begin{array}{l}0.0956 \\
(0.065)\end{array}$ & $\begin{array}{l}0.1369 \\
(0.096)\end{array}$ & & $\begin{array}{l}0.0295 \\
(0.058)\end{array}$ & 0.0158 & $\begin{array}{l}0.0070 \\
(0.079)\end{array}$ & $\begin{array}{l}0.0796 \\
(0.060)\end{array}$ \\
\hline World Real Export Growth & & 0.0100 & 0.0061 & 0.0100 & $\begin{array}{l}(0.000) \\
-0.0092\end{array}$ & & -0.0081 & -0.0076 & -0.0085 & -0.0397 & & -0.0185 & -0.0247 & -0.0252 & -0.0164 \\
\hline & & $(0.018)$ & $(0.018)$ & $(0.022)$ & $(0.047)$ & & $(0.019)$ & $(0.022)$ & $(0.022)$ & $(0.046)$ & & $(0.024)$ & $(0.025)$ & $(0.030)$ & $(0.046)$ \\
\hline IMF Emerging Mkt Dummy & & -0.0076 & $\begin{array}{r}-0.0079 \\
(0.006\end{array}$ & -0.0057 & 0.0124 & & $\begin{array}{r}-0.0080 \\
(0.008)\end{array}$ & $\begin{array}{r}-0.0091 \\
(0.008)\end{array}$ & $\begin{array}{r}-0.0021 \\
(0.011)\end{array}$ & 0.0114 & & $\begin{array}{r}-0.0063 \\
(0.007\end{array}$ & -0.0072 & 0.0015 & $\begin{array}{l}0.0093 \\
0.011)\end{array}$ \\
\hline Exchange Rate Regime & & $\begin{array}{r}(0.006) \\
-0.0008\end{array}$ & $(0.006)$ & $(0.010)$ & $(0.012)$ & & $\begin{array}{l}(0.008) \\
0.0042\end{array}$ & $(0.008)$ & $(0.011)$ & $(0.010)$ & & $\begin{array}{l}(0.007) \\
-0.0005\end{array}$ & $(0.007)$ & $(0.012)$ & $(0.011)$ \\
\hline Debt/GDP & & $(0.002)$ & $\begin{array}{l}-0.0000 \\
(0.000)\end{array}$ & & & & $(0.003)$ & $\begin{array}{l}-0.0000 \\
(0.000)\end{array}$ & & & & $(0.002)$ & $\begin{array}{r}-0.0001 \\
(0.000)\end{array}$ & & \\
\hline Original Sin & & & & $\begin{array}{l}0.0100 \\
(0.049)\end{array}$ & & & & & $\begin{array}{l}0.0325 \\
(0.050)\end{array}$ & & & & & $\begin{array}{l}0.0278 \\
(0.053)\end{array}$ & \\
\hline Financial Dollarization & & & & & $\begin{array}{l}0.0009 \\
(0.001)\end{array}$ & & & & & $\begin{array}{l}0.0004 \\
(0.001)\end{array}$ & & & & & $\begin{array}{l}0.0007 \\
(0.001)\end{array}$ \\
\hline Observations & 184 & 111 & 110 & 84 & 54 & 145 & 84 & 83 & 73 & 40 & 185 & 112 & 111 & 85 & 54 \\
\hline Nr. of countries & 59 & 55 & 55 & 47 & 28 & 45 & 42 & 42 & 41 & 22 & 60 & 56 & 56 & 48 & 28 \\
\hline $\mathrm{R}$-squared & 0.052 & 0.117 & 0.111 & 0.079 & 0.095 & 0.084 & 0.198 & 0.172 & 0.118 & 0.234 & 0.061 & 0.113 & 0.113 & 0.059 & 0.107 \\
\hline
\end{tabular}

in Columns (1), (6) and (11)) and a constant term are included but not reported. Robust standard errors in parentheses. ${ }^{* * *} \mathrm{p}<0.01,{ }^{* *} \mathrm{p}<0.05,{ }^{*} \mathrm{p}<0.1$. 
Table A3: Trade balance and openness during sudden stops

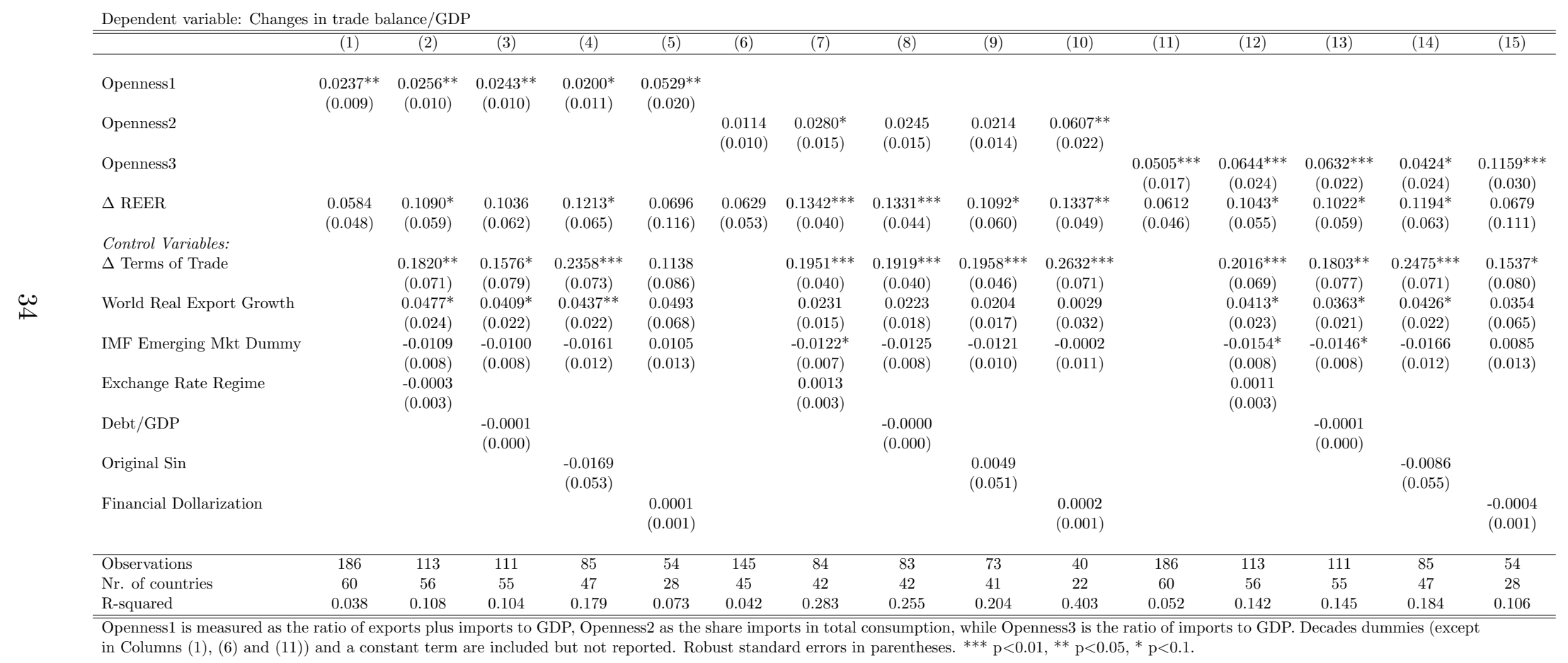


Table A4: Current account and openness during REER depreciation episodes

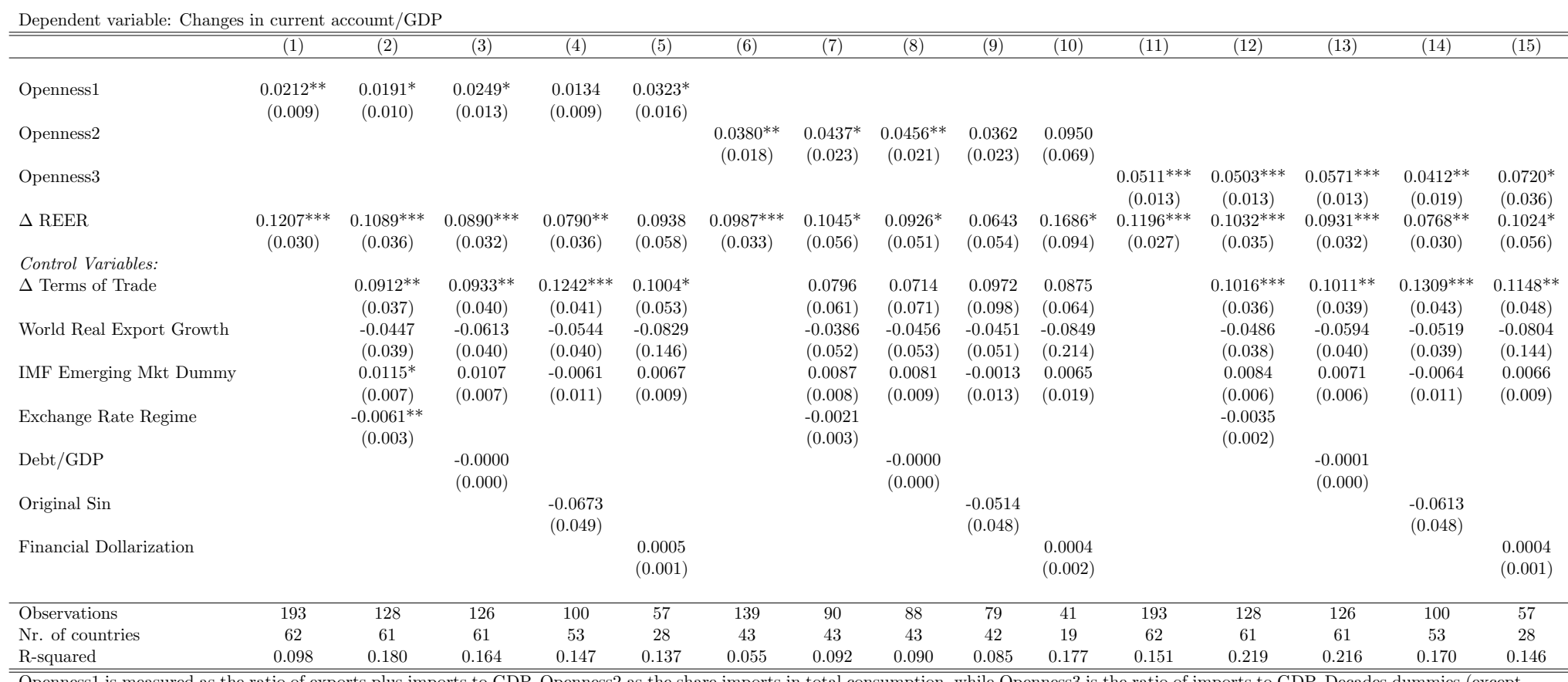

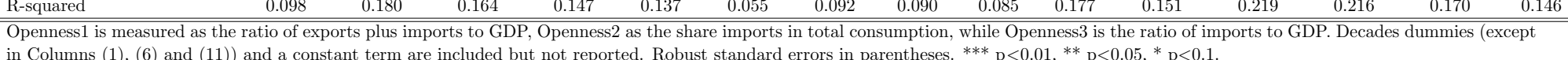


Table A5: Current account and openness during sudden stops (5 years average) estimations

Dependent variable: Changes in current account/GDP

\begin{tabular}{|c|c|c|c|c|c|c|c|c|c|c|c|c|c|c|c|}
\hline & (1) & (2) & (3) & (4) & (5) & (6) & $(7)$ & (8) & (9) & (10) & (11) & (12) & $\begin{array}{l}(13) \\
\end{array}$ & $\begin{array}{lll}(14) \\
\end{array}$ & $(15)$ \\
\hline Openness1 & $\begin{array}{c}0.0231^{* *} \\
(0.011)\end{array}$ & $\begin{array}{l}0.0206 \\
(0.013)\end{array}$ & $\begin{array}{c}0.0246^{*} \\
(0.014)\end{array}$ & $\begin{array}{l}0.0263 \\
(0.019)\end{array}$ & $\begin{array}{c}0.0671^{* * * *} \\
(0.020)\end{array}$ & & & & & & & & & & \\
\hline Openness2 & & & & & & $\begin{array}{c}0.0504^{* * *} \\
(0.018)\end{array}$ & $\begin{array}{c}0.0635^{* *} \\
(0.024)\end{array}$ & $\begin{array}{c}0.0497^{* *} \\
(0.019)\end{array}$ & $\begin{array}{c}0.0653^{* * *} \\
(0.021)\end{array}$ & $\begin{array}{c}0.0872 * * * \\
(0.030)\end{array}$ & & & & & \\
\hline Openness3 3 & & & & & & & & & & & $\begin{array}{c}0.0552^{* * *} \\
(0.020)\end{array}$ & $\begin{array}{c}0.0542^{* *} \\
(0.025)\end{array}$ & $\begin{array}{c}0.0612^{* *} \\
(0.026)\end{array}$ & $\begin{array}{l}0.0711 \\
(0.043)\end{array}$ & $\begin{array}{c}0.1105^{* * *} \\
(0.031)\end{array}$ \\
\hline$\triangle \mathrm{RER}$ & $\begin{array}{l}0.0515^{*} \\
(0.027)\end{array}$ & $\begin{array}{c}0.0865^{* *} \\
(0.037)\end{array}$ & $\begin{array}{c}0.0790^{* *} \\
(0.039)\end{array}$ & $\begin{array}{l}0.0518 \\
(0.047)\end{array}$ & $\begin{array}{l}0.0628 \\
(0.037)\end{array}$ & $\begin{array}{c}0.0590^{* *} \\
(0.023)\end{array}$ & $\begin{array}{l}0.0635 \\
(0.038)\end{array}$ & $\begin{array}{l}0.0623 \\
(0.039)\end{array}$ & $\begin{array}{l}0.0456 \\
(0.039)\end{array}$ & $\begin{array}{l}0.0604 \\
(0.039)\end{array}$ & $\begin{array}{c}0.0550^{* *} \\
(0.026)\end{array}$ & $\begin{array}{c}0.0837^{* *} \\
(0.035)\end{array}$ & $\begin{array}{c}0.0772^{* *} \\
(0.036)\end{array}$ & $\begin{array}{l}0.0497 \\
(0.043)\end{array}$ & $\begin{array}{c}0.0618^{*} \\
(0.035)\end{array}$ \\
\hline Control Variables: & & & & & & & & & & & & & & & \\
\hline$\Delta$ Terms of Trade & & $\begin{array}{c}0.1059^{* * * *} \\
(0.038)\end{array}$ & $\begin{array}{c}0.1188^{* *} \\
(0.046)\end{array}$ & $\begin{array}{l}0.0675 \\
(0.048)\end{array}$ & $\begin{array}{c}0.1431 * * \\
(0.058)\end{array}$ & & $\begin{array}{c}0.0742^{* *} \\
(0.034)\end{array}$ & $\begin{array}{l}0.0246 \\
(0.041)\end{array}$ & $\begin{array}{l}0.0633 \\
(0.038)\end{array}$ & $\begin{array}{c}0.1066^{* *} \\
(0.045)\end{array}$ & & $\begin{array}{c}0.1133^{* * *} \\
(0.035)\end{array}$ & $\begin{array}{c}0.1257^{* * * *} \\
(0.042)\end{array}$ & $\begin{array}{l}0.0979^{*} \\
(0.051)\end{array}$ & $\begin{array}{c}0.1605^{* * *} \\
(0.052)\end{array}$ \\
\hline World Real Export Growth & & $\begin{array}{l}0.0261 \\
(0.030)\end{array}$ & $\begin{array}{l}0.0151 \\
(0.029)\end{array}$ & $\begin{array}{l}0.0330 \\
(0.034)\end{array}$ & $\begin{array}{r}-0.0302 \\
(0.046)\end{array}$ & & $\begin{array}{l}0.0083 \\
(0.031)\end{array}$ & $\begin{array}{l}-0.0143 \\
(0.032)\end{array}$ & $\begin{array}{r}-0.0092 \\
(0.026)\end{array}$ & $\begin{array}{l}-0.0666 \\
(0.053)\end{array}$ & & $\begin{array}{l}0.0266 \\
(0.030)\end{array}$ & $\begin{array}{l}0.0161 \\
(0.031)\end{array}$ & $\begin{array}{l}0.0420 \\
(0.034)\end{array}$ & $\begin{array}{l}-0.0275 \\
(0.044)\end{array}$ \\
\hline IMF Emerging Mkt Dummy & & $\begin{array}{l}0.0028 \\
(0.008)\end{array}$ & $\begin{array}{l}0.0036 \\
(0.008)\end{array}$ & $\begin{array}{l}0.0052 \\
(0.014)\end{array}$ & $\begin{array}{l}0.0072 \\
(0.014)\end{array}$ & & $\begin{array}{l}0.0029 \\
(0.009)\end{array}$ & $\begin{array}{l}0.0012 \\
(0.009)\end{array}$ & $\begin{array}{l}0.0203 \\
(0.013)\end{array}$ & $\begin{array}{l}0.0155 \\
(0.014)\end{array}$ & & $\begin{array}{r}-0.0005 \\
(0.008)\end{array}$ & $\begin{array}{r}-0.0002 \\
(0.008)\end{array}$ & $\begin{array}{l}0.0038 \\
(0.013)\end{array}$ & $\begin{array}{l}0.0010 \\
(0.013)\end{array}$ \\
\hline Exchange Rate Regime & & $\begin{array}{c}-0.0070^{* *} \\
(0.003)\end{array}$ & & & & & $\begin{array}{l}0.0025 \\
(0.004)\end{array}$ & & & & & $\begin{array}{c}-0.0053^{*} \\
(0.003)\end{array}$ & & & \\
\hline Debt/GDP & & & $\begin{array}{l}-0.0001 \\
(0.000)\end{array}$ & & & & & $\begin{array}{c}-0.0004^{*} \\
(0.000)\end{array}$ & & & & & $\begin{array}{c}-0.0001 \\
(0.000)\end{array}$ & & \\
\hline Original Sin & & & & $\begin{array}{l}0.0219 \\
(0.051)\end{array}$ & & & & & $\begin{array}{l}0.0953^{*} \\
(0.051)\end{array}$ & & & & & $\begin{array}{l}0.0385 \\
(0.049)\end{array}$ & \\
\hline Financial Dollarization & & & & & $\begin{array}{l}0.0011 \\
(0.001)\end{array}$ & & & & & $\begin{array}{l}0.0007 \\
(0.001)\end{array}$ & & & & & $\begin{array}{l}0.0010 \\
(0.001)\end{array}$ \\
\hline Observations & 233 & 165 & 164 & 117 & 97 & 163 & 109 & 107 & 91 & 68 & 233 & 165 & 164 & 117 & 97 \\
\hline Nr. of countries & 83 & 77 & 77 & 62 & 46 & 56 & 51 & 51 & 49 & 33 & 83 & 77 & 77 & 62 & 46 \\
\hline R-squared & 0.049 & 0.108 & 0.090 & 0.050 & 0.144 & 0.091 & 0.108 & 0.127 & 0.118 & 0.117 & 0.081 & 0.135 & 0.125 & 0.083 & 0.157 \\
\hline
\end{tabular}


Table A6: Current account and openness during sudden stops (5 years average) estimations

\begin{tabular}{|c|c|c|c|c|c|c|c|c|c|c|c|c|c|c|c|}
\hline & $(1)$ & $\overline{(2)}$ & (3) & $\overline{(4)}$ & $(5)$ & $\overline{(6)}$ & $\overline{(7)}$ & $\overline{(8)}$ & $\overline{(9)}$ & (10) & (11) & $(12)$ & (13) & (14) & $(15)$ \\
\hline Openness1 & $\begin{array}{l}0.0187^{*} \\
(0.011)\end{array}$ & $\begin{array}{l}0.0146 \\
(0.017)\end{array}$ & $\begin{array}{l}0.0198 \\
(0.017)\end{array}$ & $\begin{array}{l}0.0161 \\
(0.018)\end{array}$ & $\begin{array}{c}0.0686^{* * *} \\
(0.017)\end{array}$ & & & & & & & & & & \\
\hline Openness2 & & & & & & $\begin{array}{c}0.0440^{* *} \\
(0.017)\end{array}$ & $\begin{array}{l}0.0519^{*} \\
(0.026)\end{array}$ & $\begin{array}{l}0.0403^{*} \\
(0.020)\end{array}$ & $\begin{array}{l}0.0505^{*} \\
(0.027)\end{array}$ & $\begin{array}{c}0.0864^{* *} \\
(0.036)\end{array}$ & & & & & \\
\hline Openness3 & & & & & & & & & & & $\begin{array}{c}0.0550^{* *} \\
(0.022)\end{array}$ & $\begin{array}{l}0.0528 \\
(0.036)\end{array}$ & $\begin{array}{l}0.0616^{*} \\
(0.035)\end{array}$ & $\begin{array}{l}0.0461 \\
(0.042)\end{array}$ & $\begin{array}{c}0.1387^{* * *} \\
(0.029)\end{array}$ \\
\hline$\Delta$ RER & $\begin{array}{c}0.0800^{* * *} \\
(0.021)\end{array}$ & $\begin{array}{c}0.1139^{* * *} \\
(0.036)\end{array}$ & $\begin{array}{c}0.0957^{* * *} \\
(0.033)\end{array}$ & $\begin{array}{c}0.0969^{* *} \\
(0.038)\end{array}$ & $\begin{array}{c}0.0672^{* *} \\
(0.031)\end{array}$ & $\begin{array}{c}0.0788^{* * * *} \\
(0.021)\end{array}$ & $\begin{array}{c}0.0924^{* *} \\
(0.037)\end{array}$ & $\begin{array}{c}0.0888^{* *} \\
(0.033)\end{array}$ & $\begin{array}{c}0.0979^{* * *} \\
(0.033)\end{array}$ & $\begin{array}{c}0.0770^{* *} \\
(0.029)\end{array}$ & $\begin{array}{c}0.0864^{* * *} \\
(0.022)\end{array}$ & $\begin{array}{c}0.1161^{* * *} \\
(0.036)\end{array}$ & $\begin{array}{c}0.1038^{* * *} \\
(0.033)\end{array}$ & $\begin{array}{c}0.0929^{* *} \\
(0.037)\end{array}$ & $\begin{array}{c}0.0847^{* * * *} \\
(0.031)\end{array}$ \\
\hline Control Variables: & & & & & & & & & & & & & & & \\
\hline$\Delta$ Terms of Trade & & $\begin{array}{c}0.1225^{* * *} \\
(0.041)\end{array}$ & $\begin{array}{c}0.1192^{* *} \\
(0.047)\end{array}$ & $\begin{array}{c}0.1236^{* *} \\
(0.056)\end{array}$ & $\begin{array}{c}0.1485 * * * \\
(0.052)\end{array}$ & & $\begin{array}{l}0.0402 \\
(0.047)\end{array}$ & $\begin{array}{l}0.0076 \\
(0.058)\end{array}$ & $\begin{array}{l}0.0330 \\
(0.054)\end{array}$ & $\begin{array}{l}0.0804 \\
(0.066)\end{array}$ & & $\begin{array}{c}0.1544^{* *} \\
(0.060)\end{array}$ & $\begin{array}{c}0.1505^{* *} \\
(0.063)\end{array}$ & $\begin{array}{c}0.1025^{* *} \\
(0.048)\end{array}$ & $\begin{array}{c}0.2242^{* * *} \\
(0.071)\end{array}$ \\
\hline World Real Export Growth & & $\begin{array}{l}-0.0031 \\
(0.029)\end{array}$ & $\begin{array}{r}-0.0136 \\
(0.029)\end{array}$ & $\begin{array}{l}-0.0088 \\
(0.035)\end{array}$ & $\begin{array}{l}0.0062 \\
(0.053)\end{array}$ & & $\begin{array}{l}0.0088 \\
(0.034)\end{array}$ & $\begin{array}{l}-0.0040 \\
-(0.035)\end{array}$ & $\begin{array}{l}-0.0022 \\
(0.034)\end{array}$ & $\begin{array}{l}-0.0503 \\
(0.045)\end{array}$ & & $\begin{array}{r}-0.0207 \\
(0.032)\end{array}$ & $\begin{array}{l}-0.0296 \\
(0.033)\end{array}$ & $\begin{array}{l}-0.0293 \\
(0.039)\end{array}$ & $\begin{array}{l}-0.0044 \\
(0.051)\end{array}$ \\
\hline IMF Emerging Mkt Dummy & & $\begin{array}{l}0.0016 \\
(0.009)\end{array}$ & $\begin{array}{l}0.0035 \\
(0.009)\end{array}$ & $\begin{array}{r}-0.0034 \\
(0.012)\end{array}$ & $\begin{array}{l}0.0086 \\
(0.014)\end{array}$ & & $\begin{array}{l}0.0025 \\
(0.008)\end{array}$ & $\begin{array}{c}-0.0006 \\
(0.008)\end{array}$ & $\begin{array}{l}0.0074 \\
(0.012)\end{array}$ & $\begin{array}{l}0.0148 \\
(0.016)\end{array}$ & & $\begin{array}{r}-0.0018 \\
(0.009)\end{array}$ & $\begin{array}{l}-0.0011 \\
(0.009)\end{array}$ & $\begin{array}{r}-0.0020 \\
(0.012)\end{array}$ & $\begin{array}{r}-0.0020 \\
(0.013)\end{array}$ \\
\hline Exchange Rate Regime & & $\begin{array}{c}-0.0087^{*} \\
(0.005)\end{array}$ & & & & & $\begin{array}{l}0.0006 \\
(0.005)\end{array}$ & & & & & $\begin{array}{c}-0.0060 \\
(0.005)\end{array}$ & & & \\
\hline Debt/GDP & & & $\begin{array}{r}-0.0002 \\
(0.000)\end{array}$ & & & & & $\begin{array}{c}-0.0003^{*} \\
(0.000)\end{array}$ & & & & & $\begin{array}{r}-0.0002 \\
(0.000)\end{array}$ & & \\
\hline Original Sin & & & & $\begin{array}{l}-0.0466 \\
(0.049)\end{array}$ & & & & & $\begin{array}{l}0.0211 \\
(0.061)\end{array}$ & & & & & $\begin{array}{r}-0.0393 \\
(0.049)\end{array}$ & \\
\hline Financial Dollarization & & & & & $\begin{array}{l}0.0019^{*} \\
(0.001)\end{array}$ & & & & & $\begin{array}{l}0.0013 \\
(0.001)\end{array}$ & & & & & $\begin{array}{l}0.0021^{*} \\
(0.001)\end{array}$ \\
\hline Observations & 291 & 176 & 174 & 125 & 93 & 180 & 111 & 108 & 95 & 66 & 293 & 178 & 176 & 126 & 94 \\
\hline Nr. of countries & 84 & 72 & 73 & 59 & 45 & 56 & 48 & 48 & 46 & 34 & 85 & 73 & 74 & 59 & 46 \\
\hline R-squared & 0.051 & 0.115 & 0.101 & 0.077 & 0.202 & 0.098 & 0.128 & 0.133 & 0.108 & 0.169 & 0.079 & 0.143 & 0.140 & 0.086 & 0.296 \\
\hline
\end{tabular}

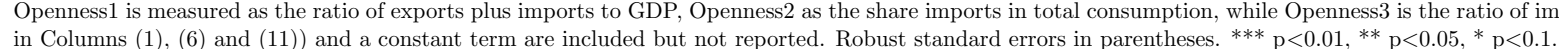


ESSEC Business School

3, avenue Bernard-Hirsch

CS 50105 Cergy

95021 Cergy-Pontoise Cedex

France

Têl. +33 (0) 134433000

www.essec.fir
ESSEC Executive Education

CNIT BP 230

92053 Paris-La Défense

France

Têl. +33 (0)146924900

www.executive-education.essec.fi
ESSEC Asia Pacific

2 One-North Gateway

Singapore 138502

Têl. +65 68849780

www.essec.edu/asia

\section{SINGAPOUR}

\section{Contact :}

Centre de Recherche

+33 (0)134433091

research.center@essec.fr 